\title{
Mating-induced Male Death and Pheromone Toxin-regulated Androstasis
}

\author{
Cheng Shi, Alexi M. Runnels, and Coleen T. Murphy* \\ Lewis-Sigler Institute for Integrative Genomics and Dept. of Molecular Biology, Princeton University, Princeton, NJ \\ 08544, USA \\ *Correspondence to: ctmurphy@princeton.edu
}

\begin{abstract}
How mating affects male lifespan is poorly understood. Using single worm lifespan assays, we discovered that males live significantly shorter after mating in both androdioecious (male and hermaphroditic) and gonochoristic (male and female) Caenorhabditis. Germline-dependent shrinking, glycogen loss, and ectopic expression of vitellogenins contribute to male post-mating lifespan reduction, which is conserved between the sexes. In addition to mating-induced lifespan decrease, worms are subject to killing by male pheromone-dependent toxicity. C. elegans males are the most sensitive, whereas $C$. remanei are immune, suggesting that males in androdioecious and gonochoristic species utilize male pheromone differently as a toxin or a chemical messenger. Our study reveals two mechanisms involved in male lifespan regulation: germline-dependent shrinking and death is the result of an unavoidable cost of reproduction and is evolutionarily conserved, whereas male pheromone-mediated killing provides a novel mechanism to cull the male population and ensure a return to the self-reproduction mode in androdioecious species. Our work highlights the importance of understanding the shared vs. sex- and speciesspecific mechanisms that regulate lifespan.
\end{abstract}

Keywords: Caenorhabditis, mating, pheromone, death

\section{Introduction}

The interplay between the sexes influences an individual's longevity ${ }^{1-3}$. Caenorhabditis female lifespan is shortened after mating through receipt of male sperm and seminal fluid ${ }^{4}$, and separately by exposure to male pheromone ${ }^{5}$. However, previous studies reported contradictory results on how mating influences male lifespan ${ }^{3,6}$. Therefore, whether and how male lifespan is affected by prolonged exposure and interactions with females is largely unknown.

The Caenorhabditis genus consists of both androdioecious (male and hermaphroditic) and gonochoristic (male and female) species. In androdioecious species such as C. elegans, the population is dominated by hermaphrodites, which reproduce by self-fertilization. Males are usually very rare (less than $0.2 \%$ for the standard lab strain $\mathrm{N} 2$ ) and are produced due to spontaneous $\mathrm{X}$ chromosome nondisjunction ${ }^{7,8}$. Under stressful conditions, more oocytes experience chromosome non-disjunction, thus androdioecious species periodically undergo explosions of male populations. The existence of males in androdioecious species may reduce inbreeding and facilitate adaptation to changing environments ${ }^{9}$. By contrast, in gonochoristic species such as
C. remanei, $50 \%$ of the population is male, and females and males must mate to reproduce. The mating efficiency of $C$. elegans males is very low compared to C. remanei males ${ }^{8}$. Gonochoristic species females secrete pheromones that attract males ${ }^{10}$, and have distinct behaviors during mating compared to hermaphrodites ${ }^{11,12}$. How males in androdioecious and gonochoristic species cope with these different mating situations remains poorly understood. Moreover, the utility of killing females by exposure to male pheromone in gonochoristic populations ${ }^{5}$ is unclear.

Here we report that after mating, Caenorhabditis males suffer from germline-dependent shrinking and death, just as in the case of mated C. elegans hermaphrodites and C. remanei females ${ }^{4}$. However, C. elegans males and hermaphrodites have differential sensitivity to male pheromone-dependent toxicity, while $C$. remanei seem immune to this toxicity, and instead use sex-specific pheromones to identify mates. Thus, androdioecious and gonochoristic species differentially utilize pheromone for mating vs hermaphroditic maintenance, while both species suffer the cost of mating through germlinedependent shrinking and death. 


\section{Results}

\section{C. elegans males live shorter after mating}

C. elegans hermaphrodites shrink up to $30 \%$ and live $40 \%$ shorter after mating ${ }^{4}$. We wondered if males also experience such extreme post-mating changes. Traditional lifespan assays are performed using grouped worms; however, grouped males live shorter than solitary males ${ }^{13}$, which could mask the lifespan shortening effect of mating in males. Therefore, we measured the lifespans of solitary males and single males paired with a single hermaphrodite for 6 days from Day 1 to Day 6 of adulthood. (We used fog-2(q71) worms in our assay; fog-2 males are equivalent to wild-type (N2) males, while fog2 hermaphrodites are self-spermless ${ }^{14}$, enabling identification of successful mating.) Mated male lifespan was decreased $\sim 35 \%$ compared with the unmated solitary males (Fig. 1A, Table S1), similar to the lifespan decrease of mated hermaphrodites ${ }^{4}$. Also like females, males shrank after 6 days' mating; by Day 7, the mated males were $10 \%$ smaller than the unmated solitary males control (Fig. 1B,C, Table S2).

Males die faster when paired with a hermaphrodite for a longer period: mating with a hermaphrodite for one day did not affect the lifespan of the male, while 2-3 days' mating shortened male lifespan by $15 \%$, 4-5 days' mating reduced their lifespan by $25 \%$, and 6 days' mating increased the reduction to over $35 \%$ (Fig. 1D). By contrast, the number of hermaphrodites paired with the single male during mating had much less effect compared to mating duration (Fig. 1E, Fig. S1A,B). The time at which mating occurs within the reproductive period is also not critical for males' post-mating
A

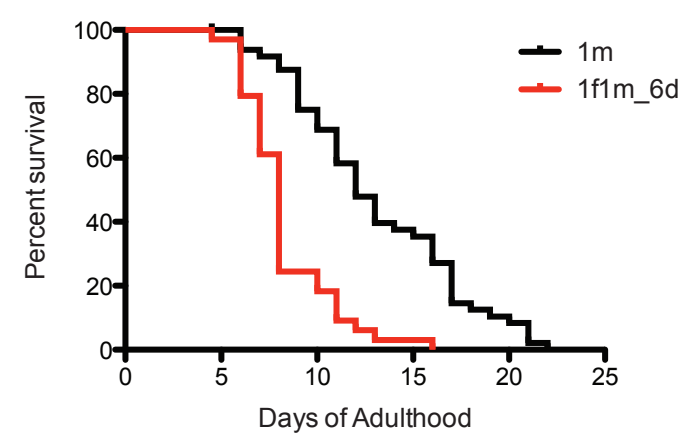

B

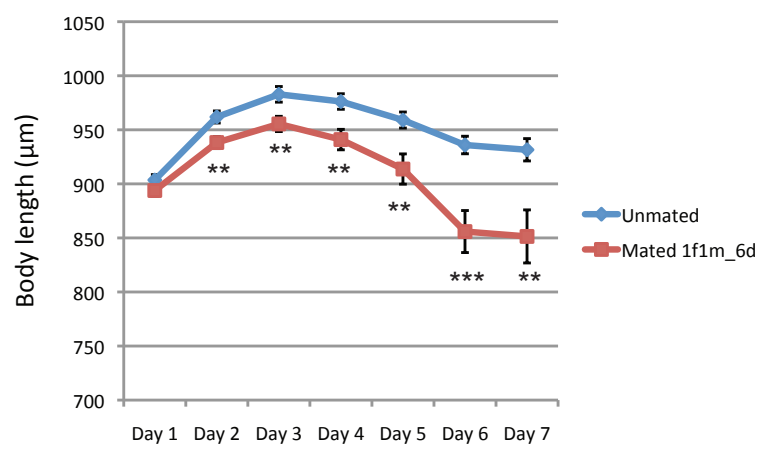

C
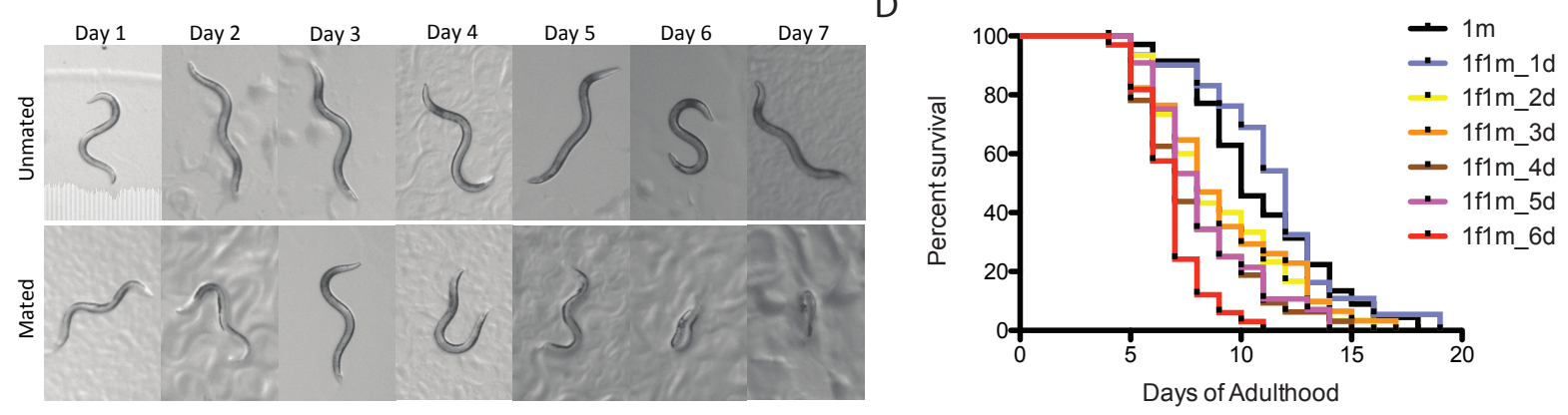

$\mathrm{E}$

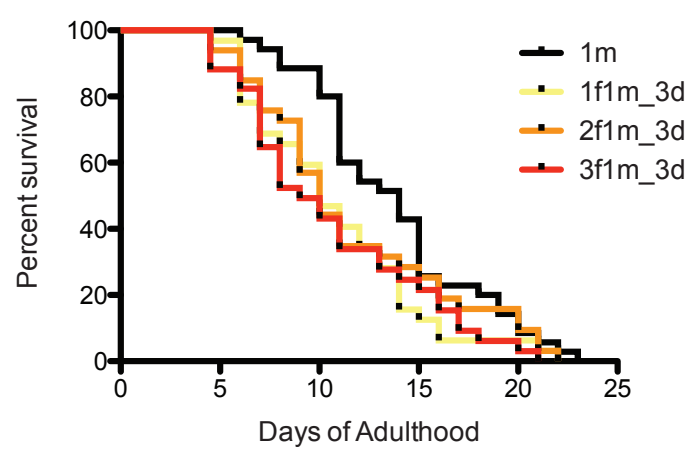

$\mathrm{F}$

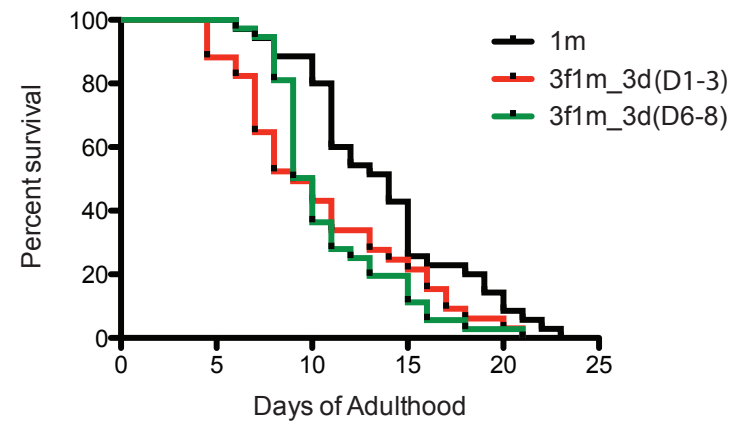

Figure 1. C. elegans males shrink and die early after mating. 
lifespan decrease; given the same mating duration, males mated with hermaphrodites for the first three days of adulthood had a similar lifespan decrease as those mated with hermaphrodites during Days 6-8 of adulthood (Fig. 1F).

\section{C. elegans males' post-mating shrinking and death are germline-dependent}

We wondered whether pheromone is required for matinginduced death in males. To distinguish pheromone from a direct mating effect, we tested daf-22(m130) mutants, which are deficient in ascaroside pheromone biogenesis ${ }^{15}$. Wild-type males still died early post-mating when paired with a daf-22 hermaphrodite for 6 days (Fig. 2A). Likewise, daf-22 mutant males lived shorter after 6 days' mating (Fig. 2B), indicating that the post-mating lifespan decrease in our single-worm pair lifespan assay is due to mating itself rather than pheromone from either sex.

A

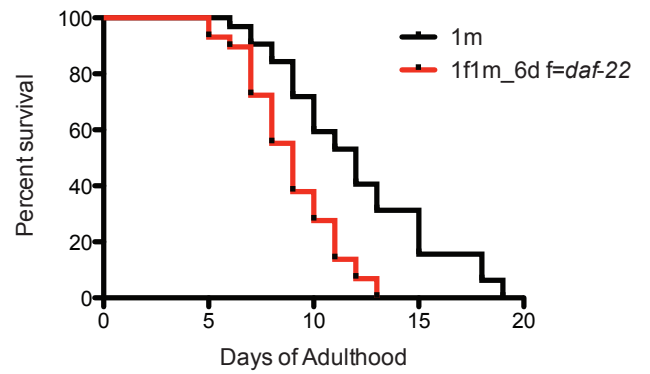

C

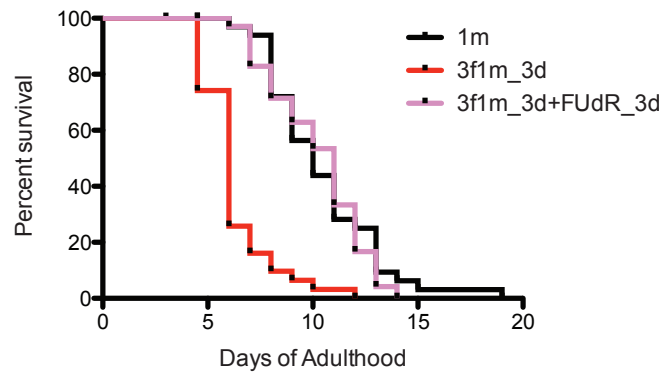

B

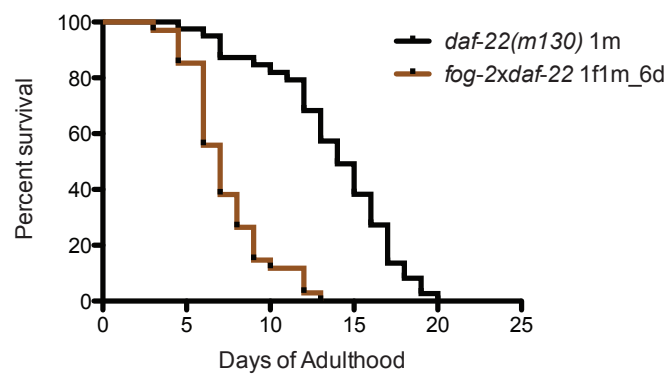

D

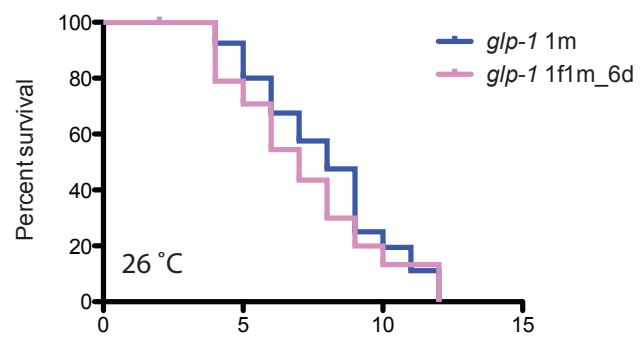

Elevated germline proliferation is one of the major causes of hermaphrodites' early death after mating ${ }^{4}$. We wondered whether this killing mechanism is conserved in males. Adult treatment with the DNA replication inhibitor 5fluorodeoxyruridine (FUdR) has little effect on lifespan and meiosis at low dosage $(50 \mu \mathrm{M})^{16}$, but rapidly blocks germline proliferation in mated hermaphrodites ${ }^{4}$. When treated with $50 \mu \mathrm{M}$ FUdR during the three-day mating period, male lifespan was unchanged (Fig. 2C). FUdR treatment also eliminated male post-mating lifespan decrease in our 6 days' mating regime (Fig. S1C,D). Additionally, lacking the germline prevented both shrinking and death: mating caused neither shrinking nor lifespan decrease in germline-less $g l p$ 1(e2141) males (Fig. 2D,E, Fig. S1E). These results suggest that germline-mediated post-mating lifespan regulation is conserved between sexes to a large extent.
$\mathrm{F}$

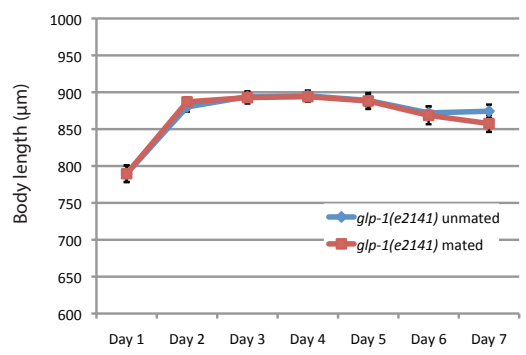

E

Figure 2 Male post-mating shrinking death is germline-dependent. 
We have shown previously that osmotic stress resistance correlates well with shrinking in mated hermaphrodites, whereas fat loss does not account for such shrinking ${ }^{4}$. Changes of glycogen levels in vivo accurately reflect the osmotic perturbation in the environment ${ }^{17}$; therefore, we measured the glycogen level using iodine staining, and found that mated wild-type worms lost about $30 \%$ of the glycogen storage postmating in a germline-dependent manner (Fig 2F). The matinginduced glycogen storage decrease and subsequent shrinking is conserved between sexes (Fig. S2).

\section{Vitellogenin dysregulation contributes to male post-mating death}

To further characterize male post-mating death, we performed genome-wide transcriptional analysis of mated and unmated males: we paired a single male with a hermaphrodite for 3.5 days of mating, then picked the males individually from the hermaphrodites on Day 4 for microarray analysis (Fig. S3A). As a control, we collected the same number of age-matched solitary males. 14 genes were significantly up-regulated and 41 were significantly down-regulated (FDR $=0 \%$; $\mathrm{SAM}^{18}$;
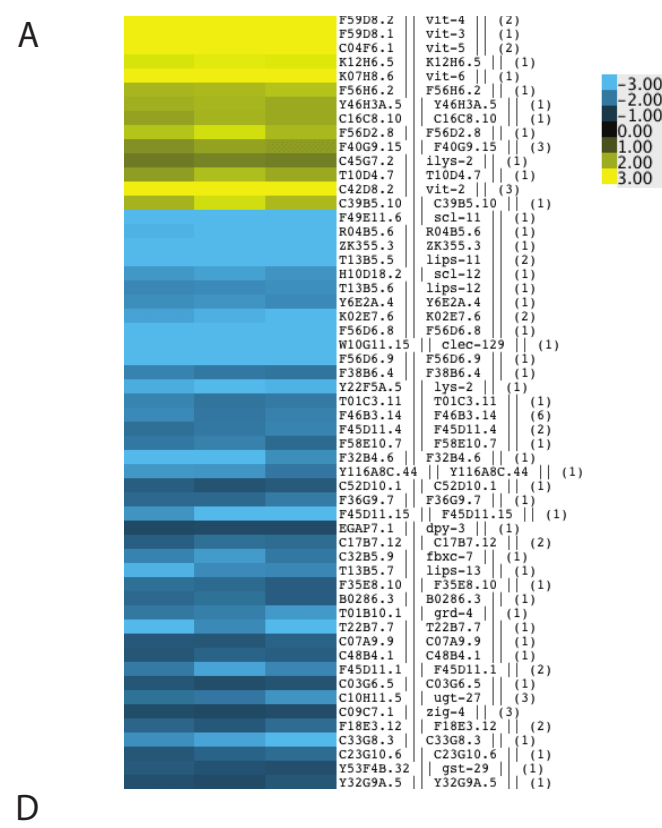

B
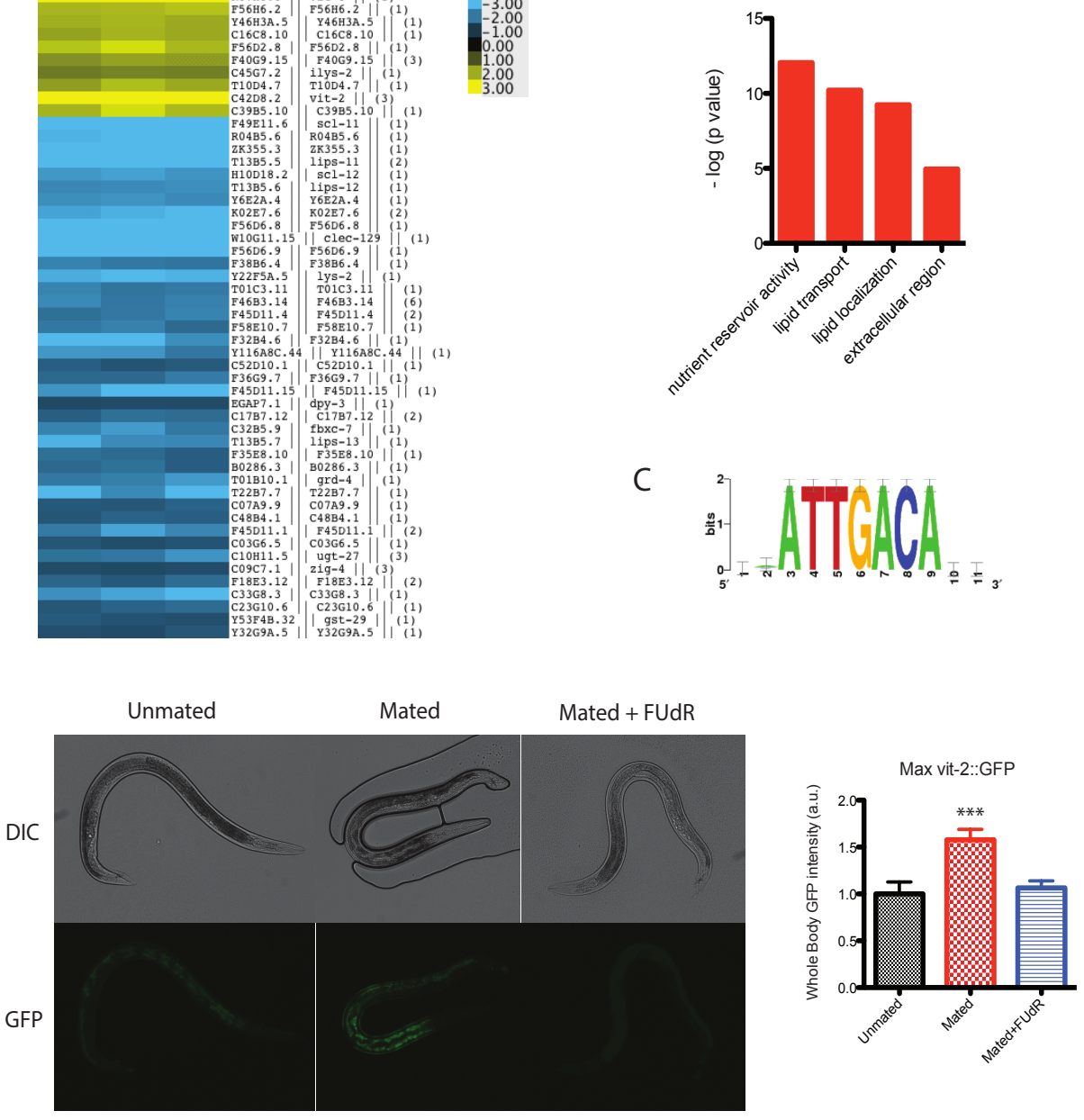

$E$

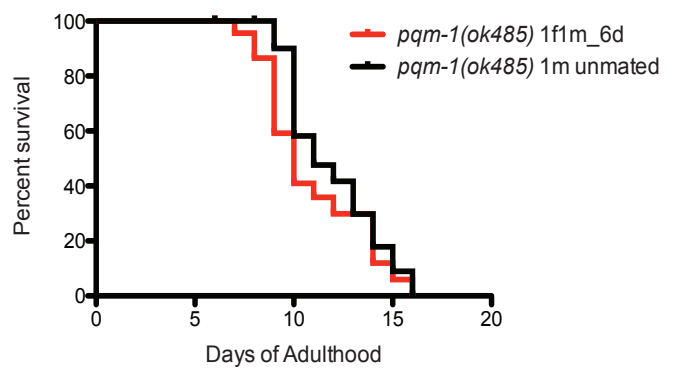

$\mathrm{F}$

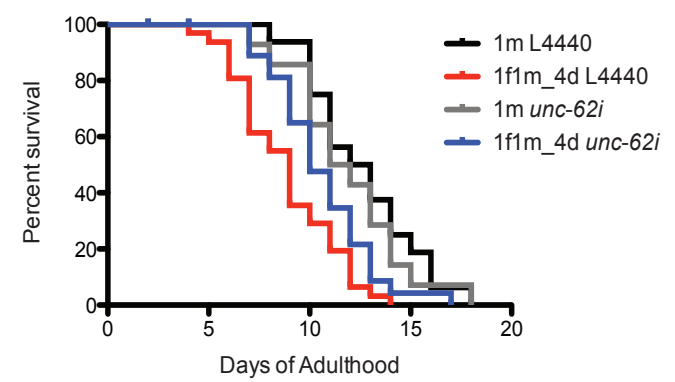


Table S3, Fig. 3A). Genes whose expression decreased in mated males include extracellular proteins ( $\mathrm{scl}-11, \mathrm{scl}-12$, zig4) and predicted lipase-related hydrolases (lips-11, lips-12, lips-13). The most enriched gene ontology (GO) categories were ribonucleoside monophosphate biosynthetic/metabolic process and extracellular region for the down-regulated genes, and nutrient reservoir activity and lipid transport for the upregulated genes (Fig. 3B, Fig. S3B).

Surprisingly, vitellogenins (vit-4, vit-3, vit-5, vit-6, vit-2), which encode yolk protein precursors made in the female/hermaphrodite intestine for transport into developing oocytes $^{19}$, were the top up-regulated genes in mated males. They were expressed on average 19 times higher in mated males than in solitary unmated males (Table S3). Males normally do not express vit genes, as they produce no oocytes. We confirmed our microarray finding using VIT-2::GFP males: mating induced ectopic expression of VIT-2::GFP, especially in the anterior intestine in males. Such overexpression was germline-dependent (Fig. 3D, S3D). Overproduction of vitellogenins is deleterious for hermaphrodites: vitellogenins accumulate in the head and body of older hermaphrodites ${ }^{20}$; long-lived insulin signaling mutants repress vit gene expression ${ }^{21}$; and knockdown of the vit genes in wild-type hermaphrodites extends lifespan ${ }^{21}$. The DAE (DAF-16 Associated Element) motif is present in most vit genes, which are also Class 2 DAF-16 genes ${ }^{21}$. Thus, we tested the function of PQM-1, the DAE-dependent transcription factor ${ }^{22}$, in male post-mating death. Mated pqm1(ok485) knockout males lived as long as the unmated control (Fig. 3E), suggesting it is important for post-mating death. The binding motif for UNC-62, a master transcription regulator of vit genes in hermaphrodites ${ }^{23}$, also emerged in unbiased motif analysis (Fig. 3C). Using RNAi, we found that knocking down unc-62 was sufficient to rescue the lifespan decrease in mated males (Fig. 3F). Thus, the mis-expression of vitellogenins upon mating contributes to post-mating death in males.

A

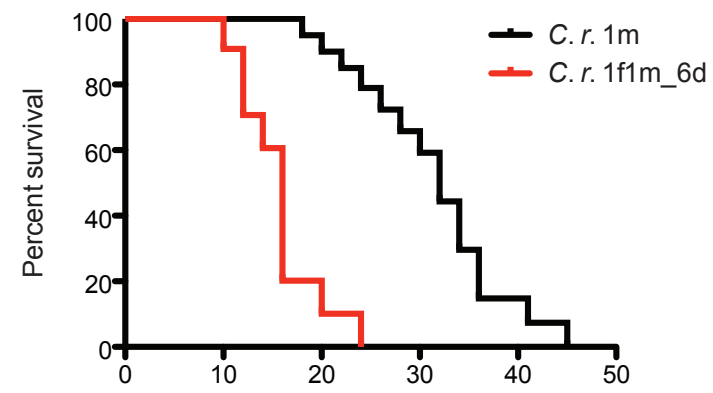

B

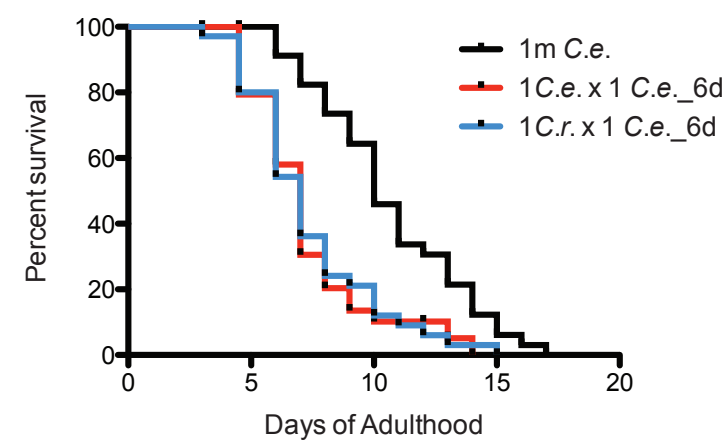

Figure 4 Mating-induced early death in males is conserved.

\section{Mating-induced early death in males is evolutionarily conserved within Caenorhabditis}

Previously, we showed that $C$. remanei females, like $C$. elegans hermaphrodites, also shrink and die faster after mating ${ }^{4}$, suggesting that the mechanisms are evolutionarily conserved in females. Likewise, we found that male $C$. remanei also lived significantly shorter after mating with a female $C$. remanei for 6 days (Fig. 4A). However, while female death requires successful cross-progeny production, as $C$. remanei males do not induce post-mating death of $C$. elegans hermaphrodites ${ }^{4}, C$. elegans males died early when mated with a $C$. remanei female for 6 days (Fig. 4B), suggesting that a component of mating specific and autonomous to the male, rather than a transferred substance or pheromone, is responsible for male death in both species.

\section{Grouped males also have reduced lifespans in $C$. elegans and $C$. remanei}

When male $C$. elegans are housed together, they live shorter compared with solitary males ${ }^{13}$, and the death rate increases with the number of males in a dose-dependent manner ${ }^{13}$ (Fig. $5 \mathrm{~A}$ ). (This might be the reason a previous report failed to report shortened lifespan of males after mating, because grouped males were used as the control $^{3}$.) C. elegans male lifespan is very sensitive to male density: just two males together significantly reduced each individual's lifespan. In a group of eight males, the individual lifespan had a more dramatic $36 \%$ decrease compared with the solitary control (Fig. 5A). C. remanei male lifespan was also influenced by male density, although to a lesser degree than $C$. elegans males (Fig. 5C). C. elegans males tend to form clumps and attempt to mate with each other. By contrast, $C$. remanei males rarely form clumps, having much reduced male-male interaction $^{13}$ (Fig. 5A,C insets). We thought such male-male mating attempts might also lead to post-mating lifespan decrease in a germline-dependent manner as we observed in males mated with females. To test this hypothesis, we placed 
the grouped males and solitary controls on FUdR plates to inhibit germline proliferation. In the presence of FUdR, grouped C. remanei males had no lifespan decrease (Fig. 5D). However, grouped $C$. elegans males still lived significantly shorter $(11 \%$ decrease compared with solitary control, $\mathrm{p}=0.0032$, Fig. 5B), indicating that a germline-independent factor also contributes to $C$. elegans male lifespan reduction when other males are present.

A

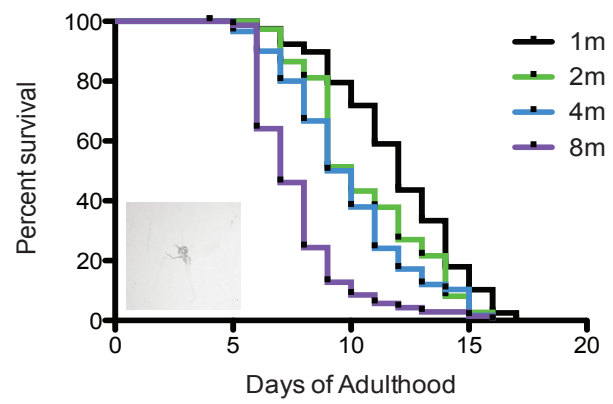

C

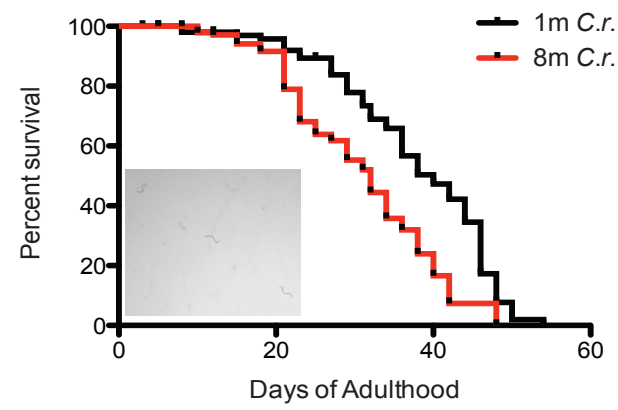

$E$

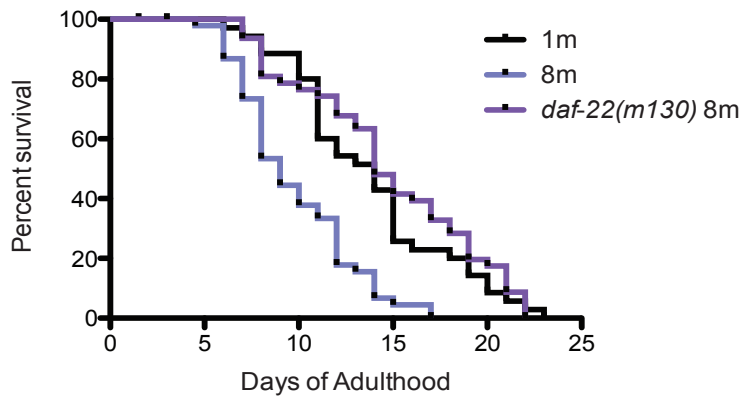

G

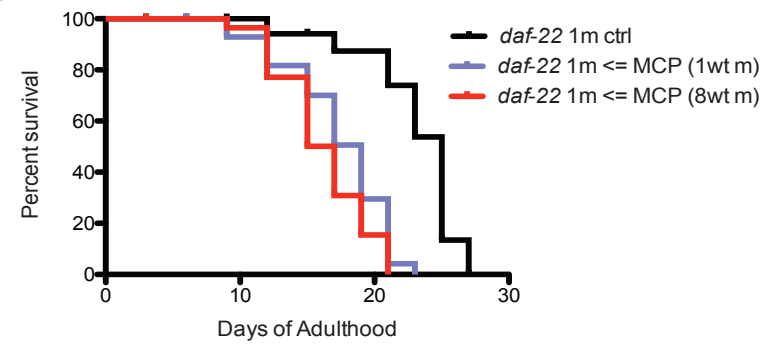

Male pheromone-dependent toxicity leads to reduced lifespan in grouped $C$. elegans

It was shown previously that $C$. elegans hermaphrodites can be killed by male pheromone secreted by grouped males ${ }^{5}$. We wondered whether male pheromone also affects male lifespan. We held 8 daf-22(m130) (pheromone-less) males together, and found that they lived as long as the solitary wild-type males, suggesting that male pheromone kills males (Fig. 5E). Grouped daf-22 males lived just slightly shorter than solitary
B

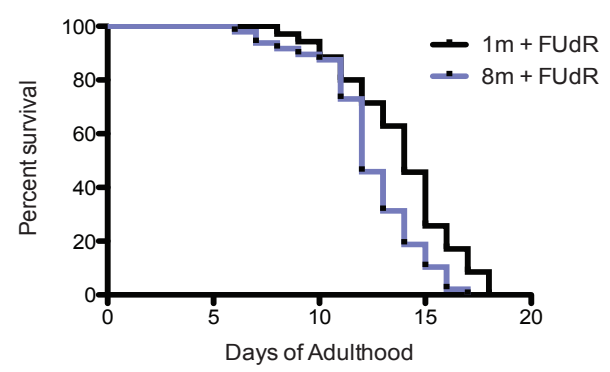

D

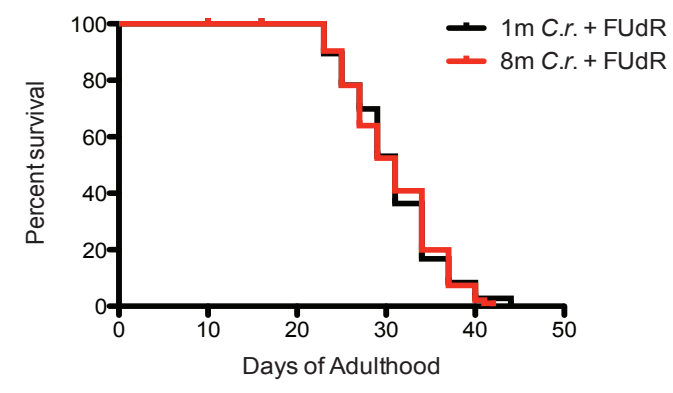

$\mathrm{F}$

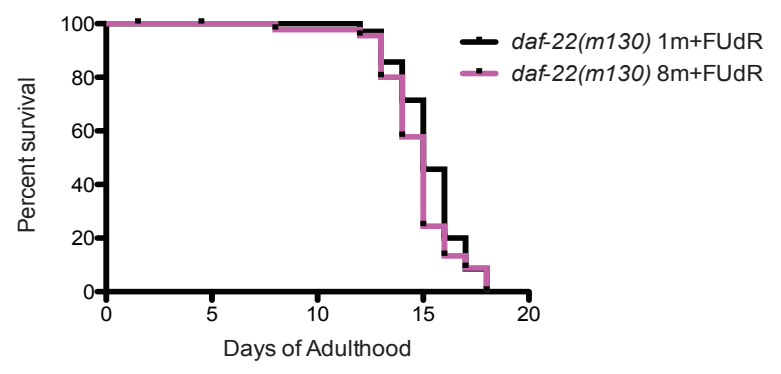


daf-22 males (Fig. S4A). The remaining lifespan difference can be explained by germline up-regulation due to mating attempts, since daf-22 males also formed clumps (Fig. S4A inset), and this lifespan difference was completely eliminated when the experiment was performed in the presence of FUdR (Fig. 5F). Therefore, in grouped C. elegans males, early death is due to a combination of germline up-regulation and male pheromone. In fact, males are the victims of their own pheromone: the lifespan of daf-22 males was significantly reduced when they were maintained on plates conditioned by only one wild-type male (Fig. 5G, S4B), suggesting that $C$. elegans males are extremely sensitive to male pheromonedependent toxicity.

\section{C. elegans and $C$. remanei have different sensitivity to male pheromone's toxicity}

We wondered whether in a true male/female species, male pheromone-mediated death is also present, and if there are cross-species effects. We confirmed that C. elegans hermaphrodites die early when grown on plates conditioned with a large number of $C$. elegans males, as shown previously ${ }^{5}$ (Fig. 6A, 30 males per plate for conditioning). C. elegans hermaphrodites also died early when exposed to $C$. remanei male pheromone (Fig. 6A). By contrast, multiple trials of $C$.

A

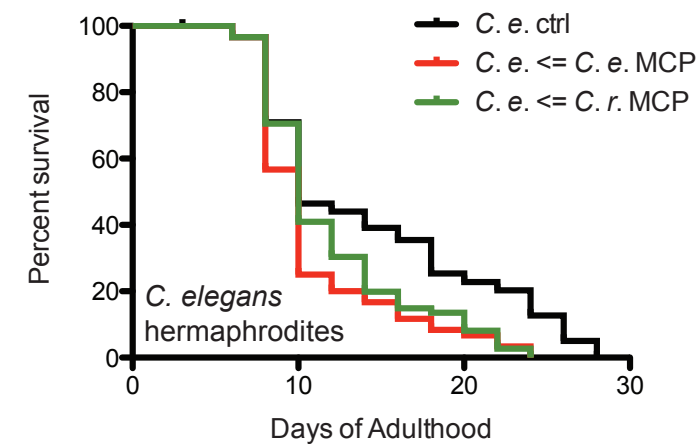

C

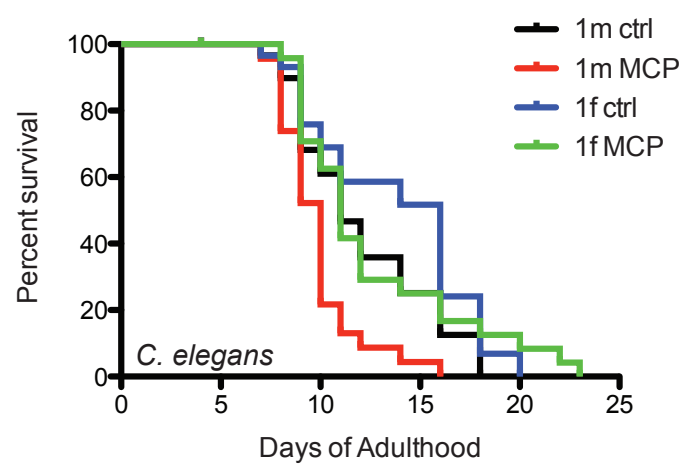

Figure 6 Only $C$. elegans is sensitive to male pheromone's toxicity.

B

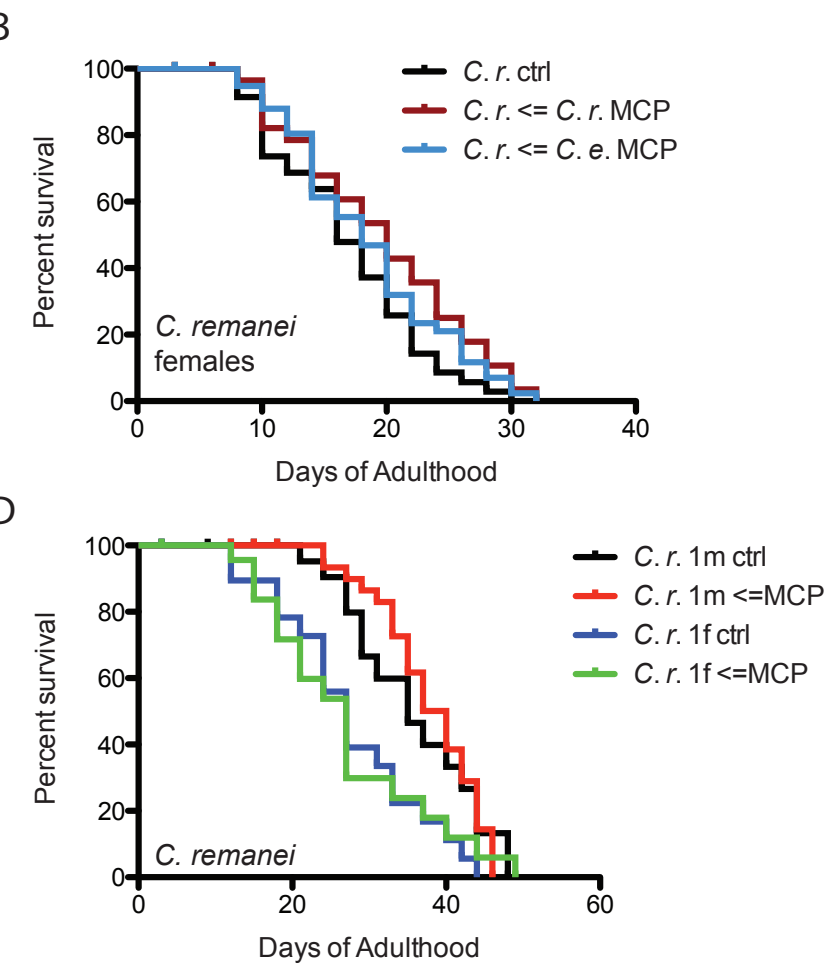

D

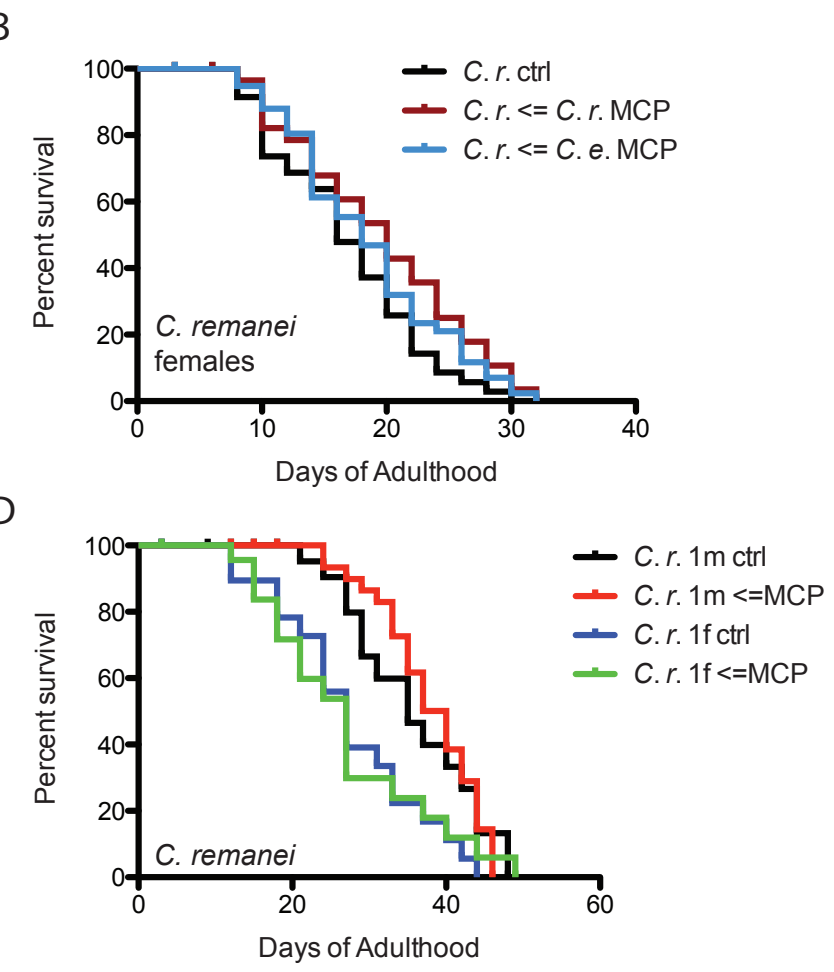

remanei females on male-conditioned plates failed to reveal any sensitivity to either remanei or elegans male pheromone (Fig. 6B). We then tested the sensitivity of both hermaphrodites and males to low levels of pheromone $(8$ males per plate for conditioning), and found that C. elegans hermaphrodites were not as sensitive to male pheromone as males were (Fig. 6C). By contrast, both C. remanei males and females were insensitive to low or high amounts of pheromone (Fig. 6D). Thus, C. elegans males are most sensitive to male pheromone-dependent toxicity, $C$. elegans hermaphrodites have intermediate sensitivity, and C. remanei appear to be immune to male pheromone toxicity (Fig. S5B).

\section{Discussion}

\section{Germline activation induces deleterious changes that cause males to die}

C. elegans males and hermaphrodites share many post-mating changes. As we found previously for mated females and hermaphrodites ${ }^{4}$, Caenorhabditis males also experience germline-dependent shrinking, glycogen loss, and death after mating. Germline up-regulation also leads to ectopic expression of vitellogenins, which contributes to the post- 
mating lifespan decrease in males. Previously, these yolk protein precursors were only noted to be expressed in hermaphrodites, since males do not produce oocytes, which normally take up vitellogenins in females. Mating also induces significant overexpression of vit genes in hermaphrodites ${ }^{24}$, indicating that vitellogenin expression is closely coupled with mating-induced germline up-regulation in both sexes. Such coupling may be strong enough to overcome the repression of male vitellogenin expression. The striking similarity of germline-dependent post-mating changes in Caenorhabditis males and females suggests that this mechanism is largely conserved between sexes, and may represent an unavoidable cost of reproduction as a result of mating.

A

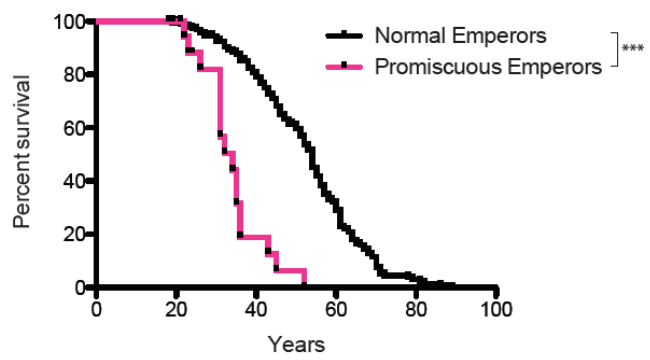

B

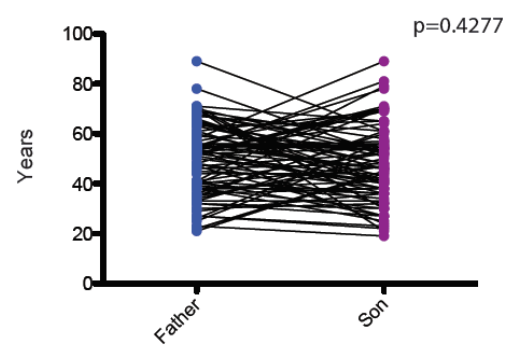

C
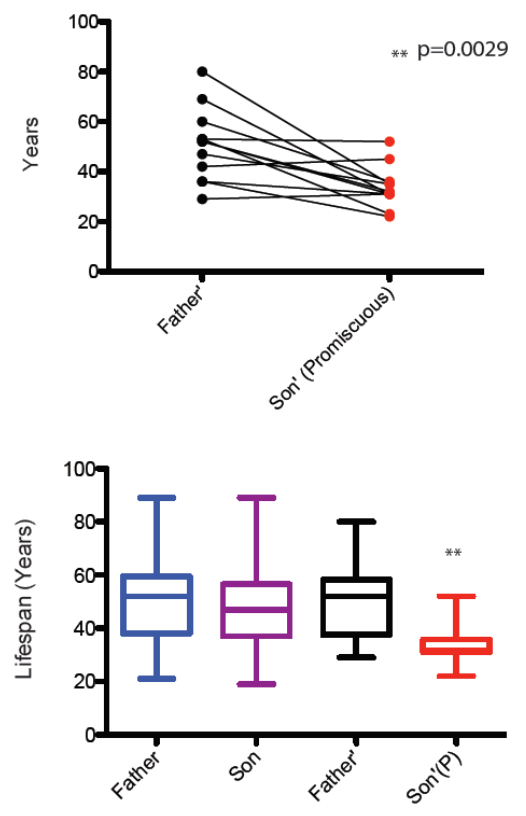

Germline-dependent lifespan shortening appears to be conserved across species over large evolutionary distances, as it occurs in all Caenorhabditis species we tested. Male postmating death is also conserved beyond the Caenorhabditis genus, as Drosophila males die earlier after mating, as well (Partridge and Farquhar 1981). To ask whether a similar phenomenon may also present in human males, we examined $>2000$ years of historical records of ancient imperial China (210 BC-1908 AD), reasoning that emperors should have had the best medical care and highest standard of living available at the time, and extensive notes regarding the emperors' behavior are available. Although our analysis is limited by the information provided in historical records in ancient China (e.g., other death-contributing factors such as sexually transmitted diseases cannot be ruled out), we censored unnatural deaths (e.g., killed in war) as we would for $C$. elegans studies, and controlled for other factors (e.g., extreme alcohol use). We found that those emperors notorious for lifelong, extremely promiscuous sexual behavior lived 35\% shorter than their counterparts ( $34 \pm 2$ yrs compared with $52 \pm$ 1 yrs, Fig. 7A, Table S4). Furthermore, analysis of father-son pairs to better control for genetic background and environmental influences (they lived in the same era, therefore had the same standard of living and medical care), still revealed a significant decrease in the lifespan of promiscuous emperors (Fig. 7B-D). While it may seem that any comparison between worms and humans in a germline effect on longevity is highly speculative, it was previously noted that the lifespan of Korean eunuchs was significantly longer than the lifespan of non-castrated men with similar socio-economic status ${ }^{25}$. Together, these results suggest that some aspects of germlinedependent male post-mating death may be evolutionarily conserved.

\section{Male pheromone-induced killing as a strategy to selectively reduce the male population}

In addition to the mating-induced lifespan decrease, $C$. elegans are subject to killing by male pheromone-dependent toxicity, while $C$. remanei are not. Our study shows that androdioecious and gonochoristic species have different sensitivities to male pheromone. The androdioecious species (C. elegans) males do not appear to use pheromones as efficiently as chemical messengers to facilitate mating, since they are less able to distinguish hermaphrodites' pheromone from other species' female or male pheromone; in fact, $C$. elegans males are even slightly attracted to their own male pheromone, in part explaining their clumping ${ }^{10}$ (Fig. S5A). On the other hand, male pheromone is very toxic to $C$. elegans males. Thus, to $C$. elegans males, pheromones serve primarily as toxins to kill males. By contrast, C. remanei (gonochoristic species) males are extremely attracted by pheromone produced by $C$. remanei females, even at a low concentration, and are slightly repelled by male pheromone ${ }^{10}$ (Fig. S5A), but $C$. remanei are immune to both elegans and remanei male pheromone toxicity (Fig. 6B,D). Thus, the gonochoristic 
species $C$. remanei uses pheromones primarily as chemical messengers to locate mates. It is also worth noting that such female pheromone-mediated attraction is completely abolished in the presence of male sperm ${ }^{10}$. In C. elegans, males are attracted to old, self-spermless hermaphrodites ${ }^{26,27}$, suggesting that pheromone retains the function as a chemical messenger under some circumstances in C. elegans. However, due to the presence of self-sperm in the hermaphrodites, $C$. elegans males do not use pheromone as a primary tool to seek young and middle-aged hermaphrodites.

Caenorhabditis species might utilize pheromones in such different ways due to their different modes of reproduction. In the androdioecious species C. elegans, males are normally rare $(0.2 \%)$, so the chance that any worm he encounters will be a hermaphrodite is very high; thus, there may be less selection pressure to evolve pheromones as chemical messengers to seek out mates. However, periodically there are explosions of male populations in androdioecious species (e.g., under stressful conditions) to allow outcrossing and ensure genetic diversity $^{9}$. After this period, however, males are more costly to maintain, and there is pressure to return to a primarily hermaphroditic population. It is notable that because $C$. elegans males are $\mathrm{XO}$, rather than $\mathrm{XY}$, males may have no selfish drive to maintain their own chromosomes. From the perspective of species, using male pheromone as a dosedependent toxin may be an effective way to cull the male population and ensure the species returns to the selfreproduction mode when the stressful condition has passed. Use of the pheromone as a toxin to kill males may have arisen to aid the return to hermaphroditism, which can also be promoted by increased hermaphroditic progeny production and decreased mating rates $^{28}$; these factors could also act in tandem with the selected pheromone-dependent killing of males. Hermaphrodite death at high male pheromone concentration (which would happen extremely rarely in nature) might simply be a rather infrequent result of collateral damage, as the hermaphrodites are less sensitive than males to the toxin. Male-specific culling also occurs in species such as Drosophila bifasciata, in which Wolbachia infection leads to the killing of male embryos, suggesting that sex ratio can be controlled through male-killing ${ }^{29}$. Mathematical modeling shows that selection in $C$. elegans favors low populations of males $^{30}$, and our model provides a mechanism for how this may be achieved.

\section{C. remanei}

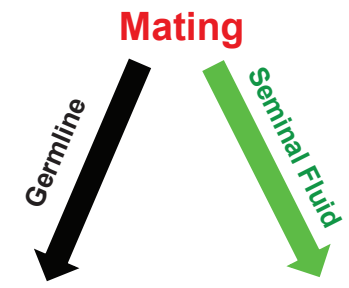

Shrinking IIS/DAF-16-

\& Death dependent death

Cost of Sperm

Reproduction Competition

c. remanei $\Upsilon^{\top}$

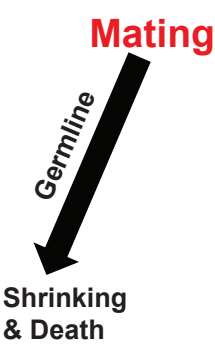

Cost of

Reproduction

Figure 8 Simplified model of how mating and male pheromone affect lifespan in $C$. elegans hermaphrodites (upper left); $C$. remanei females (upper right); $C$. elegans males (lower left); C. remanei males (lower right). 
By contrast, the preponderance of males in a 50:50 population, as in the case of C. remanei, makes the use of pheromone as a toxin less likely, as it would cause too much off-target death to be useful for sperm competition. Our cross-species results suggest that remanei male pheromone is toxic to C. elegans, but both $C$. remanei males and females are immune to both elegans and remanei pheromone (Fig. 6A,B). These results also suggest that the toxic effect of pheromone may not be due to the pheromone itself, but rather to a receptor-mediated sensitivity to pheromone that is specific to $C$. elegans, with a greater effect in males than in hermaphrodites. Instead, $C$. remanei pheromone is used to distinguish males from females, an important distinction in 50:50 mixed populations. Like $C$. elegans, the primary mode of sperm competition in C. remanei appears to involve seminal fluid transfer of factors that cause the mother to die after producing the father's progeny, before she has a chance to re-mate ${ }^{4}$, rather than through a pheromone-based mechanism (Fig. 8).

In summary, germline-dependent early death after mating is conserved between sexes and perhaps even across great evolutionarily distances, and is likely due to an unavoidable cost of mating, the result of mated animals ramping up germline proliferation and subsequently exhausting using their own resources as fast as possible to produce the next generation of progeny. The differential use of pheromones as toxins or chemical messengers by males in androdioecious and gonochoristic species demonstrates that they adopt different strategies to compete, mate, and maintain optimal population ratios.

\section{Acknowledgements}

We thank the Caenorhabditis Genetics Center (CGC) for strains, Z. Gitai and N. Wingreen for valuable discussions, and members of the Murphy laboratory for critically reading the manuscript. CS is supported by March of Dimes, and AMR by NIH 5T32GM007388-39. CTM is the Director of the Glenn Center for Aging Research at Princeton.

\section{Author Contributions}

C.S., A.M.R., and C.T.M. designed experiments. C.S. and A.M.R. performed experiments. C.S. and C.T.M. wrote the paper.

\section{References}

1. Fowler, K. \& Partridge, L. A cost of mating in female fruitflies. Nature 338, 760-761 (1989).
2. Partridge, L. \& Farquhar, M. Sexual activity reduces lifespan of male fruitflies. Nature 294, 580-582 (1981).

3. Gems, D. \& Riddle, D.L. Longevity in Caenorhabditis elegans reduced by mating but not gamete production. Nature 379, 723-725 (1996).

4. Shi, C. \& Murphy, C.T. Mating induces shrinking and death in Caenorhabditis mothers. Science 343, 536-540 (2014).

5. Maures, T.J. et al. Males shorten the life span of $C$. elegans hermaphrodites via secreted compounds. Science 343, 541-544 (2014).

6. Van Voorhies W.A. Production of sperm reduces nematode lifespan. Nature 360, 456-458 (1992).

7. Hodgkin, J. Male phenotypes and mating efficiency in Caenorhabditis elegans. Genetics 103, 43-64 (1983).

8. Chasnov, J.R. \& Chow, K.L. Why are there males in the hermaphrodites species Caenorhabditis elegans? Genetics 160, 983-994 (2002).

9. Anderson, J.L., Morran, L.T. \& Phillips, P.C. Outcrossing and the maintenance of males within $C$. elegans populations. J. Hered. 101, S62-74 (2010).

10. Chasnov, J.R., So, W.K., Chan, C.M. \& Chow, K.L. The species, sex, and stage specificity of a Caenorhabditis sex pheromone. Proc. Natl. Acad. Sci. U.S.A. 104, 6730-6735 (2007).

11. Garcia, L.R., LeBoeuf, B. \& Koo P. Diversity in mating behavior of hermaphroditic and male-female Caenorhabditis nematodes. Genetics 175, 1761-1771 (2007).

12. Kleemann, G.A. \& Basolo, A.L. Facultative decrease in mating resistance in hermaphroditic Caenorhabditis elegans with self-sperm depletion. Anim. Behav. 74, 1339-1347 (2007).

13. Gems, D. \& Riddle, D.L. Genetic, behavioral and environmental determinants of male longevity in Caenorhabditis elegans. Genetics 154, 1597-2610 (2000).

14. Schedl, T. \& Kimble, J. fog-2, a Germ-Line-Specific Sex Determination Gene Required for Hermaphrodite Spermatogenesis in Caenorhabditis elegans. Genetics 119, 43-61 (1988).

15. Golden, J.W. \& Riddle, D.L. A gene affecting production of the Caenorhabditis elegans dauerinducing pheromone. Mol. Gen. Genet. 198, 534-536 (1985).

16. Luo, S., Shaw, W., Ashraf, J. \& Murphy, C.T. TGF- $\beta$ $\mathrm{Sma} / \mathrm{Mab}$ signaling mutations uncouple reproductive aging from somatic aging. PLoS Genetics 5, e1000789 (2009).

17. Frazier, H.N. \& Roth, M.B. Adaptive sugar provisioning controls survival of C. elegans embryos in adverse environments. Curr. Biol. 19, 859-863 (2009). 
18. Tusher, V.G., Tibshirani, R. \& Chu, G. Significance analysis of microarrays applied to the ionizing radiation response. Proc Natl Acad Sci US A 98, 5116-5121 (2001).

19. Kimble, J. \& Sharrock, W.J. Tissue-specific synthesis of yolk proteins in Caenorhabditis elegans. Developmental Biology 96, 189-196 (1983).

20. Garigan, D. et al. Genetic analysis of tissue aging in Caenorhabditis elegans: a role for heat-shock factor and bacterial proliferation. Genetics 161; 1101-1112 (2002).

21. Murphy, C.T. et al. Genes that act downstream of DAF-16 to influence the lifespan of Caenorhabditis elegans. Nature 424, 277-283 (2003).

22. Tepper, R.G. et al. PQM-1 complements DAF-16 as a key transcriptional regulator of DAF-2-mediated development and longevity. Cell 154, 676-690 (2013).

23. Van Nostrand, E.L., Sanchez-Blanco, A., Wu, B., Nguyen, A. \& Kim, S.K. Roles of the developmental regulator unc-62/homothorax in limiting longevity in Caenorhabditis elegans. PLoS Genetics 9, e1003325 (2013).

24. DePina, A.S. et al. Regulation of Caenorhabditis elegans vitellogenesis by DAF-2/IIS through separable transcriptional and posttranscriptional mechanisms. BMC Physiology 11: 11 (2011).

25. Min, K., Lee, C. \& Park, H. The lifespan of Korean eunuchs. Curr. Biol. 22, R792-793 (2012).

26. Morsci, N.S., Hass, L.A. \& Barr, M.M. Sperm status regulates sexual attraction in Caenorhabditis elegans. Genetics 189, 1341-1346 (2011).

27. Leighton, D.H.W., Choe, A., Wu, S.Y. \& Sternberg, P.W. Communication between oocytes and somatic cells regulates volatile pheromone production in Caenorhabditis elegans. Proc Natl Acad Sci U S A 111, 17905-17910 (2014).

28. Wegewitz, V., Schulenburg, H. \& Streit, A. Experimental insight into the proximate causes of male persistence variation among two strains of the androdioecious Caenorharbditis elegans (Nematoda). BMC Ecology 8: 12 (2008).

29. Stevens, L., Giordano, R. \& Fialho, R. Male-killing, nematode infections, bacteriophage infection, and virulence of cytoplasmic bacteria in the genus Wolbachia. Annual Review of Ecology and Systematics 32, 519-545 (2001).

30. Stewart, A.D. \& Phillips, P.C. Selection and maintenance of androdioecy in Caenorhabditis elegans. Genetics 160, 975-982 (2002).

31. Luo, S., Kleemann, G.A., Ashraf, J.M., Shaw, W.M. $\&$ Murphy, C.T. TGF- $\beta$ and insulin signaling regulate reproductive aging via oocyte and germline quality maintenance. Cell 143, 299-312 (2010).

\section{Materials and Methods}

\author{
Strains: \\ CB4108: fog-2(q71) $\mathrm{V}$ \\ CB4037: $g l p-1(e 2141)$ III \\ DR476: daf-22(m130) II \\ RT130: pwIs23 [vit-2::GFP] (translational fusion) \\ PB4641: Caenorhabditis remanei
}

\section{Individual male mating lifespan assays:}

All the lifespan assays were performed at room temperature (about $20-21^{\circ} \mathrm{C}$ ); except for $g l p-1$ males' lifespan assays (performed at $25-26^{\circ} \mathrm{C}$ ). $35 \mathrm{~mm}$ NGM plates were used for all the experiments in this study. $20 \mu 1$ of OP50 was dropped onto each plate to make a bacterial lawn of $\sim 10 \mathrm{~mm}$ diameter. The next day, one synchronized late L4 male and one late L4 hermaphrodite/female were transferred onto each $35 \mathrm{~mm}$ NGM plate. For experiments in Fig. 1E, 1F, S1A-B,D, 2C, multiple L4 hermaphrodites were transferred together with one male. One late L4 male of the same age and genotype was transferred onto the control plates. Except for Fig. 2A, fog2(q71) hermaphrodites were used as the hermaphrodites in the mating assay, because fog-2 hermaphrodites do not have self sperm, thus allowing us to easily detect successful mating (i.e. eggs and progeny on the plates). We only included males that were able to produce progeny in our analysis. However, for the experiments regarding $g l p-1$ males, mating on FUdR, and inter-species cross between C. elegans males and C. remanei females, we included all the males in the analysis. Worms were transferred onto new plates every other day. If the hermaphrodites were lost or bagged, new unmated Day 1 fog2 hermaphrodites were added as replacement. Males and hermaphrodites/females were kept together for 6 days (unless noted otherwise in the text); afterwards only males were transferred on to newly seeded plates every 2-3 days. For RNAi experiments in Fig. 3F, synchronized eggs were transferred onto NGM plates with RNAi bacteria, late L4 males were transferred and paired with fog-2 L4 hermaphrodites onto NGM plates seeded with OP50 (to eliminate the possible effect on mating efficiency for different RNAi treatments). Two days later, males and hermaphrodites were transferred onto fresh plates seeded with corresponding RNAi bacteria and males were maintained on RNAi bacteria thereafter. When lifespan assays were completed, KaplanMeier analysis with log-rank (Mantel-Cox) method was performed to compare the lifespans of different groups.

\section{Grouped males:}

$35 \mathrm{~mm}$ NGM plates were used for all the experiments in this study. $20 \mu \mathrm{l}$ of OP50 was dropped onto each plate to make a bacterial lawn of $\sim 10 \mathrm{~mm}$ diameter. The next day, eight 
synchronized late L4 males were transferred onto each plate. (Two or four males per plate for experiment in Fig. 5A.) One late L4 male of the same age and genotype was transferred onto the control plates. Males were transferred onto fresh plates every two days, when the males were lost or dead, males from other plates were transferred together to make the size of the group stable.

\section{Male-conditioned plates (MCP) setup:}

Male-conditioned plates for lifespan assays were prepared as previously described ${ }^{5}$. Briefly, $60 \mu 1$ of OP50 was dropped onto each $35 \mathrm{~mm}$ NGM plate to make a bacterial lawn of $\sim 25$ $\mathrm{mm}$ diameter. Young Day 1 wild-type males (fog-2 males) were transferred onto each plate. Two days later, they were removed and worms for lifespan assays were immediately transferred onto these male-conditioned plates. These maleconditioned plates were being prepared throughout the course of the lifespan assays (Fig. S4B). For the experiments in Fig. $6 \mathrm{~A}, \mathrm{~B}, 30$ males were used for each conditioning plate. For experiments in Fig. 6C,D, 8 males were used for conditioning and for the experiment in Fig. 5G, only 1 male was used for conditioning for each plate.

\section{Body size measurement:}

Images of live males on $35 \mathrm{~mm}$ plates were taken daily for the first week of adulthood with a Nikon SMZ1500 microscope. Image $\mathrm{J}$ was used to analyze the body size of the worms. The middle line of each worm was delineated using the segmented line tool and the total length was documented as the body length of the worm. T-test was performed to compare the body size differences between groups of males in the same day.

\section{FUdR experiment:}

FUdR was added to the NGM media to the final concentration of $50 \mu \mathrm{M}$. Late L4 males and hermaphrodites were transferred onto NGM+FUdR plates seeded with OP50. Worms were transferred every two days, and were kept on FUdR plates for different period of time ( 3 days, 6 days or lifetime as indicated by text).

\section{Glycogen staining:}

Glycogen staining was performed according to a welldescribed protocol ${ }^{17}$. Mating of males was set up as previously described. Right before staining, live males of the same group were picked into a M9 droplet with $1 \mathrm{M}$ sodium azide on a $3 \%$ agarose pad. Immediately after the liquid was dry, the pad was inverted over the opening of a $50 \mathrm{~g}$ bottle of iodine crystal chips (Sigma) for 1 minute. After the color stained by iodine vapor on the pad disappear (non-specific staining), the worms were immediately imaged by a Nikon microscope. Due to uncontrollable differences, it is hard to compare the staining performed at different times. Thus, worms from the groups of comparison were mounted onto the same pad (separate M9 droplet if there is no visible difference). Image $J$ was used to compare the mean intensity of iodine staining after the background was subtracted. T-test was performed to compare the staining between different groups (on the same pad).

\section{GFP intensity quantification:}

10-20 worms of each group were imaged by Nikon Ti. Image $\mathrm{J}$ was used to measure the mean and the maximum GFP intensity of the whole body area. T-test analysis was performed to compare the GFP intensity of different groups of worms.

\section{Mated males microarrays:}

We paired a single male with a fog-2 hermaphrodite for about 3.5 days of mating, then picked the males individually from the hermaphrodites on Day 4 for microarray analysis. As a control, solitary males were collected at the same time. About 150 males (on 150 individual $35 \mathrm{~mm}$ plates) were collected for each condition and replicate. Three biological replicates were performed. RNA was extracted by heat-vortexing method. Two-color Agilent microarrays were used. The detailed steps and analysis were performed according to a previous report ${ }^{31}$.

\section{Pheromone chemotaxis assay:}

This assay was modified from a previous assay ${ }^{10}$. 10 Day 1 virgin $C$. remanei or $C$. elegans hermaphrodites were put in $100 \mu 1$ of M9 buffer at room temperature overnight with shaking. 100 males of either C. elegans or C. remanei were put in $100 \mu 1$ of M9. The supernatant solutions were then taken for pheromone chemotaxis assay. $60 \mathrm{~mm}$ NGM plates (no food) were used for the chemotaxis assay. Two destination spots (supernatant and M9 control) were separated by about 45 $\mathrm{mm}$, the distance from the origin spot to either destination spot is $30 \mathrm{~mm}$. Two $1 \mu 1$ drops of $1 \mathrm{M}$ sodium azide were first applied to the destination spots. When dry, a drop of $1 \mu 1 \mathrm{M} 9$ or supernatant was separately added onto the destination spots. Then, over 10 young adult (Day 2) males were placed at the origin spot (try to transfer as little bacteria as possible). After 60 minutes, the paralyzed male worms were scored based on their location. The chemotaxis index was calculated as: (\#worms at supernatant destination - \#worms at control destination)/(\#total worms - \#worms at origin).

\section{Analysis of Lifespans of Emperors in Imperial China:}

In ancient China, agriculture was the main source of the 
country's wealth. The development of agriculture began in the Neolithic Era (10,000 BC), followed by improvements in the Bronze Age (1000 BC). Late in the Warring states eras (771$221 \mathrm{BC}$ ), new iron tools were widely adopted, which revolutionized agriculture in China. Ancient China's economy depended heavily if not solely on agriculture.

Qin Shi Huang (\#1 on the list below) was the first emperor to unify China. By that time, agriculture had already been well developed and the basic structure and the quality of civilization did not change much until the late 1800s. Emperors had the best standard of living and medical care at the time, and the living conditions of emperors in Imperial China (220 BC -1911) remained relatively similar (i.e., the best of agricultural civilization) over this period of 2000 years.

To perform our lifespan analysis analogously with the approach we use to assess worm lifespan, we only included emperors who were over 18 years old when they died and those who reigned over 1 year, in order to exclude the cases of puppet emperors (Table S4). Those rows marked by grey on the list indicate that the emperor's death is unnatural (killed in a war, rebellion, etc); we censored these emperor at the time of death, analogously to how we would censor worms who died unnaturally or disappeared during a lifespan assay. Those highlighted in yellow are emperors with extremely promiscuous sexual behaviors, as documented by official historical records. Those labeled by shaded yellow means they were considered promiscuous but died unnaturally.

The average lifespan of promiscuous emperors was 34 years, which is $35 \%$ shorter than the normal emperors' lifespan (52 years) (Fig. 7, Table S4). It should be noted that these promiscuous emperors were also noted to indulge in excessive alcohol consumption; however, other emperors who were well-known for their lifelong alcohol indulgence were not short-lived (Examples are Yuan Tai Zong \#216 on the list, died at 56; Yuan Shi Zu \#219 died at 79).

Another case worth noting is Song Gao Zong (\#178), who was originally fertile but is reported to have become infertile when he fled south after defeat by his enemies. By the time he reestablished his dynasty in southern China, he was only 24 , but was reportedly no longer capable of reproduction; he died at the age of 81 . His case may suggest the link between germline signal and lifespan, perhaps in the same manner as the suggested lifespan extension of Korean eunuchs documented by Min, et al. (2012).

\section{Analysis of father-son comparisons:}

To better control for genetic background and environmental influences, the lifespans of father and son emperors was compared. The reasons we chose to compare father and son instead of emperor and his brothers are twofold: 1) historical records about emperors' brothers are much less extensive as those of the emperors themselves; 2) most brothers were killed by the emperor (or his ally) to ensure his ascendency and to secure his sovereignty.

\section{Main Figure Legends}

\section{Abbreviations and nomenclature in the paper:}

C. e.: C. elegans

C. r.: C. remanei

1f1m_6d: "f" stands for hermaphrodite/female, "m" stands for male, the number before $\mathrm{f} / \mathrm{m}$ suggests the amount of worms on the same $35 \mathrm{~mm}$ plate. " $6 \mathrm{~d}$ " means mating for 6 days.

AAA x BBB: hermaphrodites/females of genotype AAA are mated with males of genotype BBB. (male is always listed after the " $x$ ")

MCP: male-conditioned plates

Figure 1. C. elegans males shrink and die early after mating.

(A) Lifespans of unmated solitary and mated fog-2(q71) males. Solitary males: $13.1 \pm 0.6$ days, $n=50$; mated males: $8.3 \pm 0.4$ days, $\mathrm{n}=34, \mathrm{p}<0.0001$. Each male was paired with a fog-2(q71) hermaphrodite on a single $35 \mathrm{~mm}$ plate during Day 1-6 of adulthood. Unless noted, all the hermaphrodites used are fog2(q71). For all the lifespan assays performed in this study, Kaplan-Meier analysis with log-rank (MantelCox) test was used to determine statistical significance. All the lifespan results are included in Table S1.

(B) Length of unmated and mated fog-2 males: t-test, $* * p<0.01, * * * p<0.001$.

(C) Representative pictures of the same unmated solitary male and male paired with one hermaphrodite from Day 1-Day 6 of adulthood.

(D) Male post-mating lifespan decrease is mating duration-dependent: Unmated solitary males: $10.9 \pm$ 0.6 days, $\mathrm{n}=35$; one male and one hermaphrodite mating on Day 1 of adulthood: $11.4 \pm 0.6$ days, $n=31$, $\mathrm{p}=0.3697$; mating from Day 1-2: $9.0 \pm 0.6$ days, $\mathrm{n}=30, \mathrm{p}=0.0325$; mating from Day 1-3: $9.1 \pm 0.6$ days, $\mathrm{n}=34, \mathrm{p}=0.0452$; mating from Day 1-4: $7.9 \pm$ 0.5 days, $\mathrm{n}=32, \mathrm{p}=0.0002$; mating from Day 1-5: 8.3 \pm 0.4 days, $\mathrm{n}=34, \mathrm{p}=0.0006$; mating from Day 1-6: $6.8 \pm 0.3$ days, $\mathrm{n}=33, \mathrm{p}<0.0001$.

(E) Lifespans of one male paired with different number of hermaphrodites during Day 1-3 of adulthood: solitary unmated males: $13.8 \pm 0.7$ days, $n=35$; one male with one hermaphrodite: $10.8 \pm 0.6$ days, $\mathrm{n}=32$, 
$\mathrm{p}=0.0175$; one male with two hermaphrodites: $11.6 \pm$ 0.9 days, $\mathrm{n}=33, \mathrm{p}=0.1435$; one male with three hermaphrodites: $10.6 \pm 0.8$ days, $n=34, p=0.0147$.

(F) Lifespans of one male paired with three hermaphrodites for 3 days but at different time of adulthood. Solitary unmated males: $13.8 \pm 0.7$ days, $\mathrm{n}=35$; mating during Day 1-3 of adulthood: $10.6 \pm$ 0.8 days, $\mathrm{n}=34, \mathrm{p}=0.0147$; mating during Day $6-8$ of adulthood: $10.8 \pm 0.6$ days, $\mathrm{n}=37, \mathrm{p}=0.0022$.

Figure 2. Male post-mating shrinking death is germlinedependent.

(A) Lifespans of $f o g-2$ males mated with daf-22(m130) hermaphrodites. Unmated solitary fog-2 males: 12.1 \pm 0.6 days, $n=32$; mated males: $9.0 \pm 0.4$ days, $n=29$, $\mathrm{p}=0.0001$. In the mated group, one fog-2(q71) male was paired with one daf-22(m130) hermaphrodite from Day 1- Day 6 of adulthood.

(B) Lifespans of unmated and mated daf-22(m130) males. Unmated solitary daf-22(m130) males: $13.8 \pm$ 0.6 days, $\mathrm{n}=40$; mated daf-22(m130) males: $7.4 \pm 0.4$ days, $\mathrm{n}=34, \mathrm{p}<0.0001$. In the mated group, one daf$22(\mathrm{~m} 130)$ male was paired with one fog-2(q71) hermaphrodite from Day 1- Day 6 of adulthood.

(C) FUdR can rescue male post-mating early death. Unmated solitary males: $10.5 \pm 0.5$ days, $n=35$; one male with three hermaphrodites for three days: $6.4 \pm$ 0.3 days, $n=31, p<0.0001$; one male with three hermaphrodites for three days but in the presence of $50 \mu \mathrm{M}$ FUdR during the three days' mating: $10.2 \pm$ 0.4 days, $n=36, p=0.7086$ (compared with unmated solitary group).

(D) Lifespans of unmated and mated $g l p-1($ e2141) males: unmated solitary $g l p-1$ males: $8.0 \pm 0.4$ days, $\mathrm{n}=40$; mated $g l p-1$ males: $7.2 \pm 0.4$ days, $\mathrm{n}=40, \mathrm{p}=0.3178$. The assay was performed at $26{ }^{\circ} \mathrm{C}$, in mated group, one $g l p-1$ male was paired with one fog-2 hermaphrodite from Day 1-6.

(E) Length of mated and unmated glp-1(e2141) males. (The same population as in Fig. 2D)

(F) Glycogen staining of mated and unmated males. Left: mated fog-2 (wt) males lost over $30 \%$ glycogen after 5 days' mating. *** $\mathrm{p}<0.001$. Right: mated glp-1 males had a similar amount of glycogen as the unmated $g l p-1$ males. The staining intensity was normalized to unmated males of each genotype. Representative pictures are shown above the quantitation. Unmated males are framed by dashed lines, and mated males are framed by solid lines.

\section{Figure 3. Microarray analysis reveals vitellogenin's role in male post-mating death.}

(A) Expression heatmap of genes whose expression is significantly changed in mated males based on SAM analysis.

(B) Enriched GO terms for significantly up-regulated genes in mated males.

(C) Enriched motif associated with significantly upregulated genes predicted by RSAT (Regulatory Sequence Analysis Tools).

(D) Ectopic expression of VIT-2::GFP in mated males is germline- dependent. 5 days' mating, pictures were taken on Day 6 of adulthood. Left: images; right: quantification of VIT-2::GFP expression [maximum $\pm \mathrm{SE}$ (error bars)], a.u., arbitrary units. ***,p<0.001, t-test.

(E) pqm-1(ok485) mated males have similar lifespans as unmated controls. Unmated solitary pqm-1(ok485) males: $11.9 \pm 0.5$ days, $\mathrm{n}=25$; mated pqm-1(ok485) males: $11.0 \pm 0.6$ days, $n=29, \mathrm{p}=0.2782$. In the mated group, one pqm-1(ok485) male was paired with one fog-2(q71) hermaphrodite from Day 1- Day 6 of adulthood.

(F) unc-62 RNAi suppresses male post-mating early death. Unmated solitary male on L4440: $12.6 \pm 0.7$ days, $\mathrm{n}=25$; mated males on L4440: $8.8 \pm 0.5$ days, $\mathrm{n}=33, \mathrm{p}=0.0001$. Unmated males on unc-62 RNAi: $11.9 \pm 0.8$ days, $\mathrm{n}=25$; mated males on $u n c-62$ RNAi: $10.6 \pm 0.5$ days, $\mathrm{n}=34, \mathrm{p}=0.1249$ (compared to unmated males on $u n c-62$ RNAi).

\section{Figure 4. Mating-induced early death in males is conserved.}

(A) Mated C. remanei males also live shorter. Unmated solitary $C$. remanei males: $31.4 \pm 1.7$ days, $\mathrm{n}=72$; mated $C$. remanei males: $15.7 \pm 1.2$ days, $\mathrm{n}=28$, $\mathrm{p}<0.0001$. In mated group: one $C$. remanei male was paired with one $C$. remanei female from Day 1 -Day 6 of adulthood.

(B) Lifespans of $C$. elegans males mated with $C$. elegans hermaphrodites and $C$. remanei females. Unmated solitary $C$. elegans males: $10.2 \pm 0.6$ days, $n=35 ; C$. elegans males mated with $C$. elegans hermaphrodites: $7.4 \pm 0.4$ days, $\mathrm{n}=35, \mathrm{p}=0.0001 ; C$. elegans males mated with $C$. remanei females: $7.4 \pm$ 0.4 days, $\mathrm{n}=35, \mathrm{p}=0.0003$. In mated groups, one $C$. elegans male was paired with either one $C$. elegans hermaphrodite or one C. remanei female from Day 16 of adulthood. 
Figure 5. Grouped $C$. elegans males live shorter due to male pheromone.

(A) Lifespans of grouped fog-2(q71) males. Solitary males: $12.0 \pm 0.4$ days, $n=40$; two males: $10.6 \pm 0.4$ days, $\mathrm{n}=40, \mathrm{p}=0.0397$; four males: $9.9 \pm 0.4$ days, $\mathrm{n}=60, \mathrm{p}=0.0012$; eight males: $7.7 \pm 0.2$ days, $\mathrm{n}=80$, $\mathrm{p}<0.0001$. Inset: clumping of fog-2 males.

(B) Lifespans of grouped fog-2(q71) males in the presence of $50 \mu \mathrm{M}$ FUdR. Solitary males: $13.9 \pm 0.4$ days, $n=35$; eight males: $12.4 \pm 0.3$ days, $n=48$, $\mathrm{p}=0.0032$.

(C) Lifespans of grouped C. remanei males. Solitary males: $37.9 \pm 1.1$ days, $n=120$; eight males: $31.0 \pm$ 0.9 days, $\mathrm{n}=160, \mathrm{p}<0.0001$. Inset: $C$. remanei males rarely form clumps.

(D) Lifespans of grouped $C$. remanei males in the presence of $50 \mu \mathrm{M}$ FUdR. Solitary males: $30.8 \pm 0.9$ days, $\mathrm{n}=45$; eight males: $30.8 \pm 0.5$ days, $\mathrm{n}=112$, $\mathrm{p}=0.9217$.

(E) Grouped $d a f-22(m 130)$ males have similar lifespan to solitary wild-type $f \circ g-2$ males. Solitary fog- 2 males: $13.8 \pm 0.7$ days, $\mathrm{n}=35$; eight fog- 2 males: $9.8 \pm 0.5$ days, $\mathrm{n}=48, \mathrm{p}<0.0001$; eight daf-22(m130) males: $14.7 \pm 0.7$ days, $\mathrm{n}=48, \mathrm{p}=0.4039$ (compared to solitary males).

(F) Lifespans are not different between solitary and grouped daf-22(m130) in presence of FUdR. Solitary daf-22(m130): $15.3 \pm 0.3$ days, $\mathrm{n}=35$; eight daf$22(m 130): 14.7 \pm 0.3$ days, $n=48, p=0.2117$.

(G) $d a f-22(m 130)$ male lifespans on plates conditioned by wild-type fog- 2 males. MCP: male-conditioned plates. Solitary daf-22(m130): $23.0 \pm 0.9$ days, $\mathrm{n}=30$; daf-22(m130) on plates conditioned by one fog-2 male: $17.3 \pm 0.7$ days, $\mathrm{n}=29, \mathrm{p}<0.0001$; daf22(m130) on plates conditioned by eight fog-2 male: $16.1 \pm 0.6$ days, $n=30, p<0.0001$. Details about maleconditioned plates lifespan assays are included in Methods and Fig. S4B.

Figure 6. Only $C$. elegans is sensitive to male pheromone's toxicity.

(A) Lifespans of grouped C. elegans fog-2 hermaphrodites on plates conditioned with 30 males. fog-2 hermaphrodites control: $14.4 \pm 0.8$ days, $\mathrm{n}=90$. fog-2 hermaphrodites on plates conditioned by fog-2 males: $10.9 \pm 0.6$ days, $\mathrm{n}=60, \mathrm{p}=0.0004$; fog-2 hermaphrodites on plates conditioned by $C$. remanei males: $11.9 \pm 0.5$ days, $n=90, \mathrm{p}=0.0042$.

(B) Lifespans of grouped C. remanei females on plates conditioned by 30 males. C. remanei females on control plates: $15.8 \pm 0.9$ days, $\mathrm{n}=60 ; C$. remane $i$ females on plates conditioned by $C$. remanei males: $19.5 \pm 1.3$ days, $\mathrm{n}=30, \mathrm{p}=0.0636 ; C$. remanei females on plates conditioned by $C$. elegans fog- 2 males: 18.5 \pm 10.9 days, $\mathrm{n}=60, \mathrm{p}=0.1770$.

(C) Lifespans of solitary C. elegans fog-2 males and hermaphrodites on plates conditioned by eight fog- 2 males. Solitary fog- 2 males on control plates: $12.1 \pm$ 0.6 days, $\mathrm{n}=30$; solitary fog- 2 males on maleconditioned plates: $9.8 \pm 0.4$ days, $n=28, \mathrm{p}=0.0046$. Solitary fog-2 hermaphrodites on control plates: 13.8 \pm 0.7 days, $\mathrm{n}=30$; solitary fog- 2 hermaphrodites on male-conditioned plates: $12.6 \pm 0.9$ days, $\mathrm{n}=29$, $\mathrm{p}=0.5965$.

(D) Lifespans of solitary C. remanei males and females on plates conditioned by eight $C$. remanei males. Solitary $C$. remanei males on control plates: $35.8 \pm$ 2.0 days, $\mathrm{n}=34$; solitary $C$. remanei males on maleconditioned plates: $37.8 \pm 1.2$ days, $n=34, \mathrm{p}=0.8501$. Solitary $C$. remanei females on control plates: $27.6 \pm$ 2.2 days, $\mathrm{n}=24$; solitary $C$. remane $i$ females on maleconditioned plates: $27.0 \pm 2.5$ days, $n=30, p=0.8306$.

Figure 7. Average lifespan of Chinese emperors

(A) Average lifespan of promiscuous Chinese emperors (34 $\pm 2 \mathrm{yrs}, \mathrm{n}=21)$ is $35 \%$ shorter than that of nonpromiscuous emperors (52 \pm 1 yrs, $n=234)$, $\mathrm{p}<0.0001$. See Methods and Table S4 for detailed rationale, description, and data.

(B) There is no lifespan difference between pairs of normal father and son emperors. Father: $49 \pm 2$ yrs; Son: $48 \pm 2$ yrs, $\mathrm{p}=0.4277, \mathrm{n}=89$, paired t-test.

(C) The promiscuous son emperor lives significantly shorter than his father emperor. Father': $51 \pm 4$ yrs; promiscuous son: $34 \pm 2$ yrs; $p=0.0029, n=12$, paired t-test. The reasons we chose to compare emperor father and son instead of emperor and his brothers are that 1) historical records about emperors' brothers are much less extensive as those of the emperors themselves; 2) most of these brothers were usually killed by the emperor (or his ally) to ensure his ascendency and to secure his sovereignty.

(D) Lifespan summary of (B) and (C).

Figure 8. Simplified model of how mating and male pheromone affect lifespan in $C$. elegans hermaphrodites (upper left); C. remanei females (upper right); C. elegans males (lower left); $C$. remanei males (lower right). 
bioRxiv preprint doi: https://doi.org/10.1101/034181; this version posted November 22, 2016. The copyright holder for this preprint (which was

A

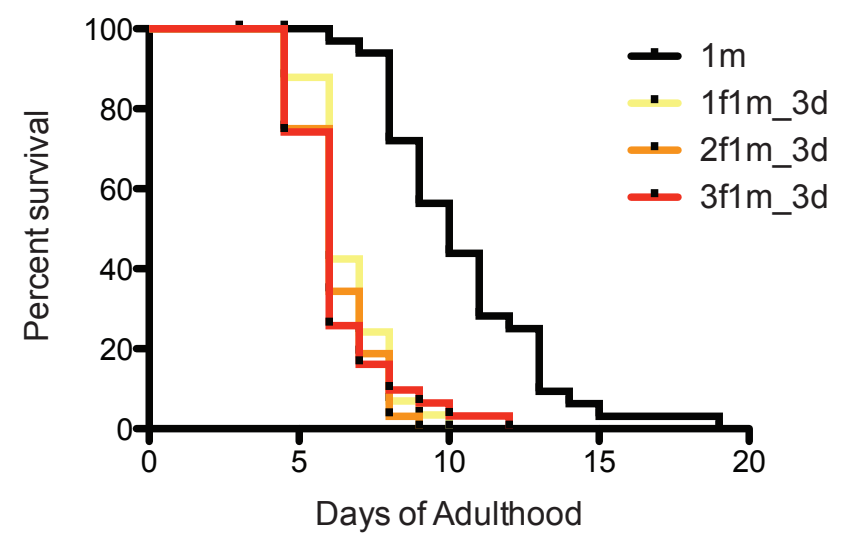

C

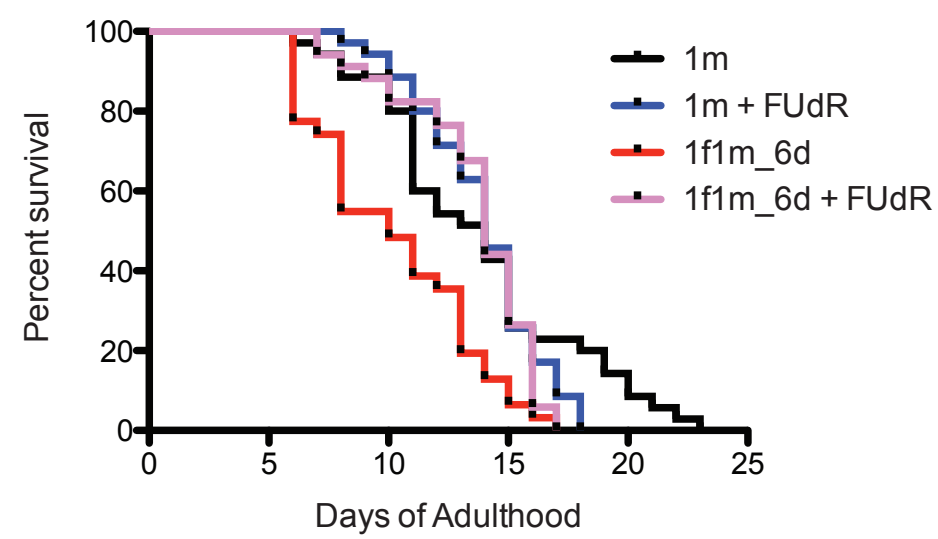

E

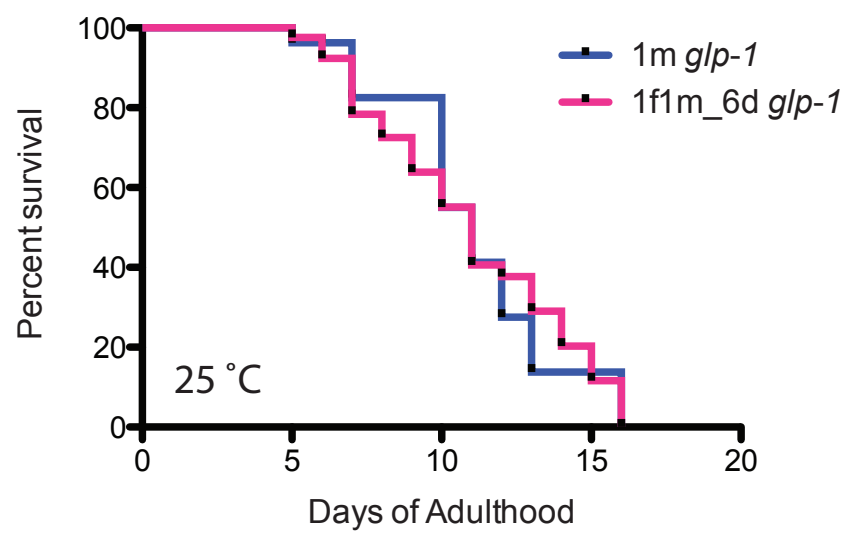

B

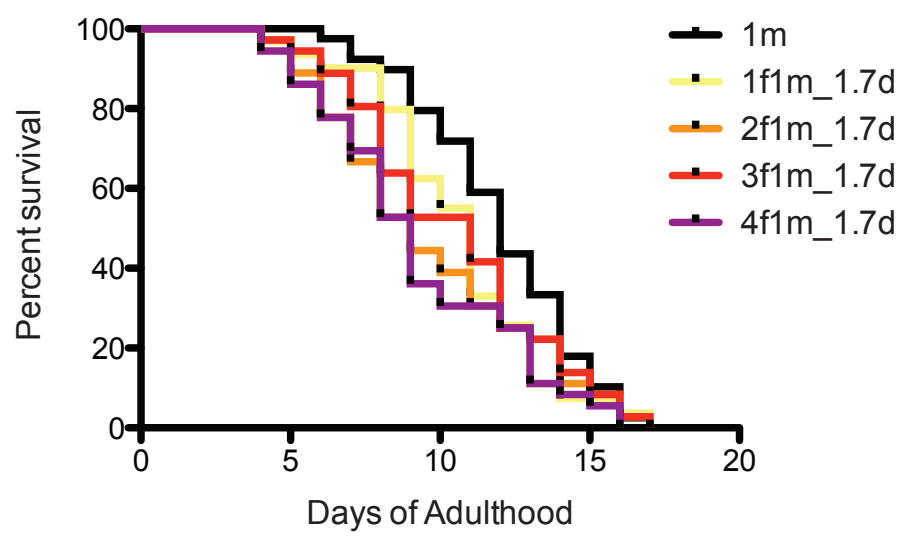

D

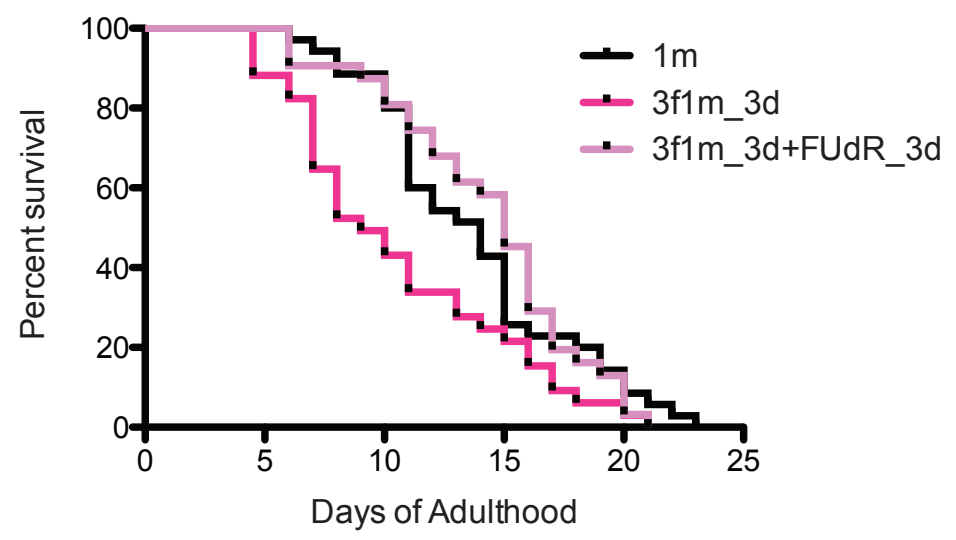


bioRxiv preprint doi: https://doi.org/10.1101/034181; this version posted November 22, 2016. The copyright holder for this preprint (which was not certified by peer review) is the author/funder. All rights reserved. No reuse allowed without permission.
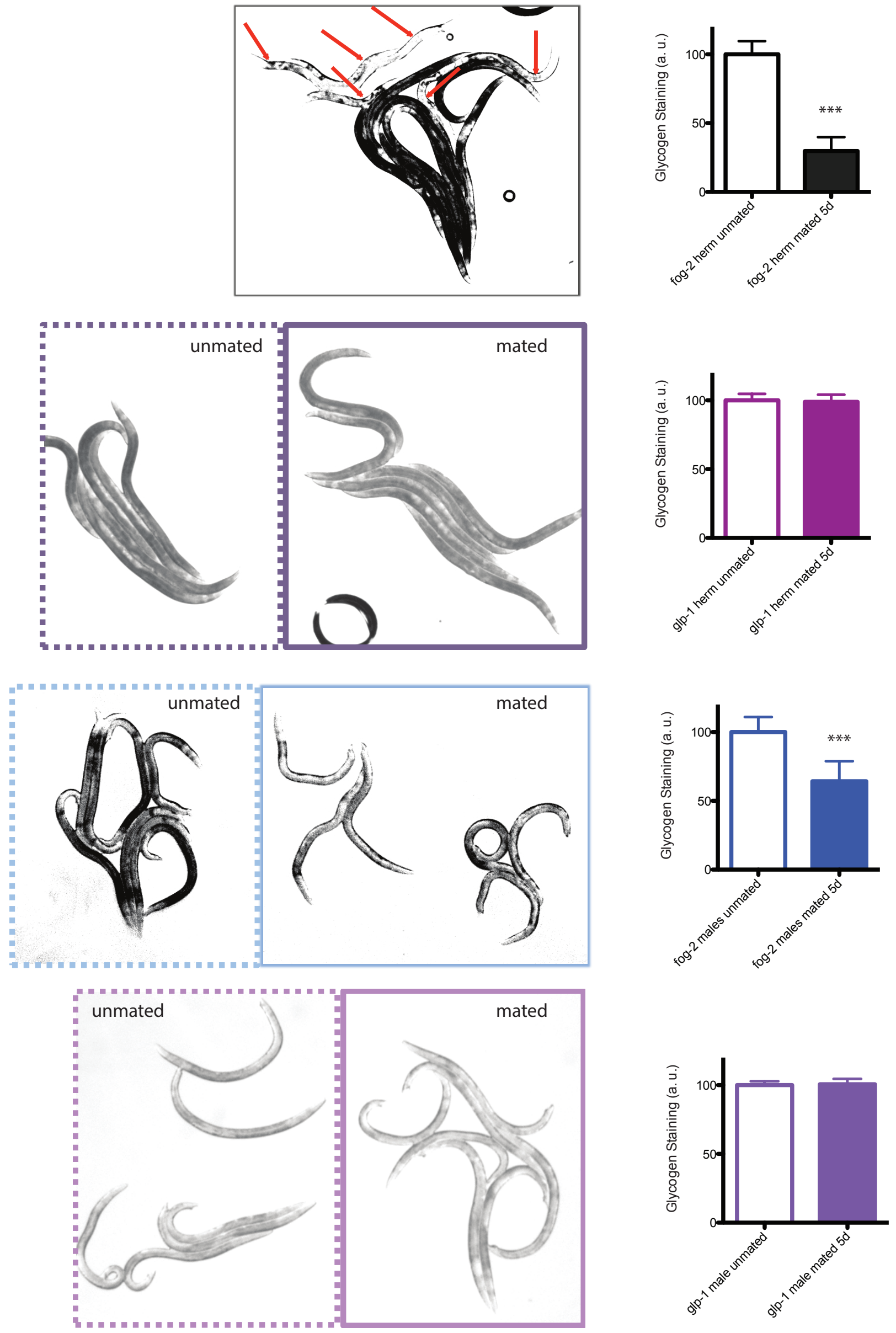
bioRxiv preprint doi: https://doi.org/10.1101/034181; this version posted November 22, 2016. The copyright holder for this preprint (which was not certified by peer review) is the author/funder All rights reserved. No reuse allowed without permission.

A

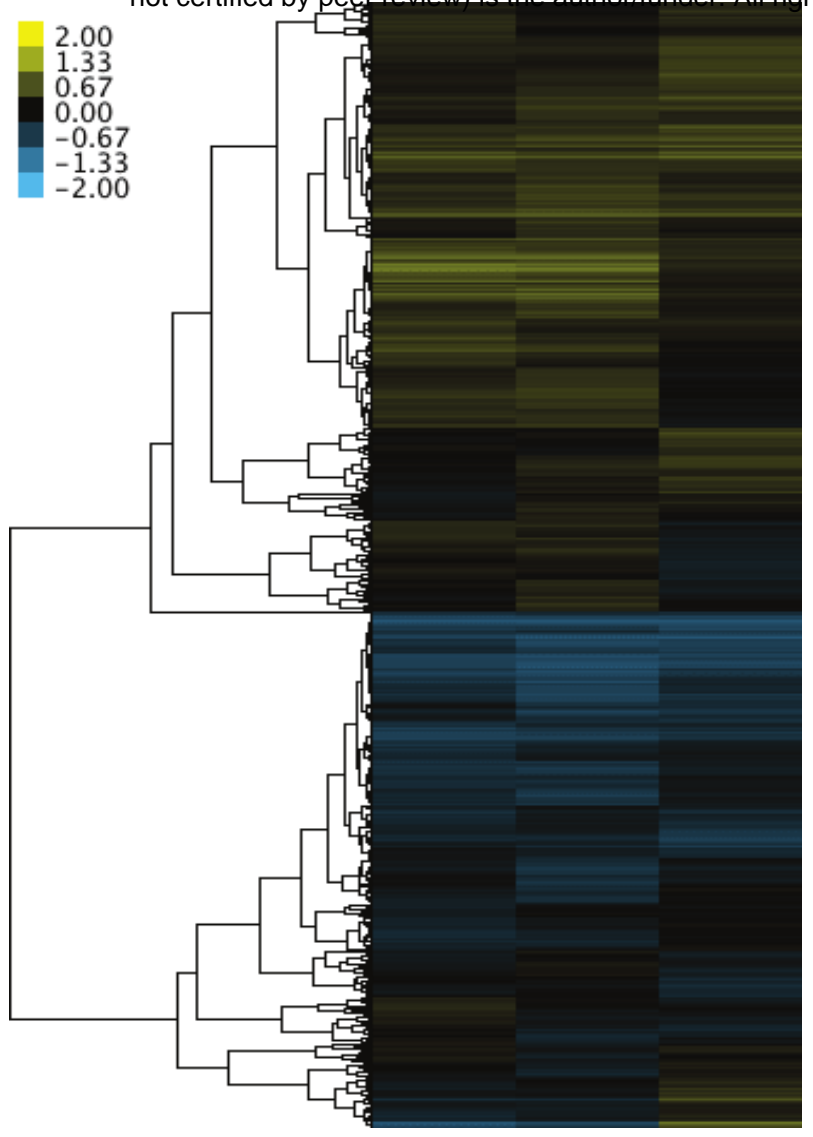

C

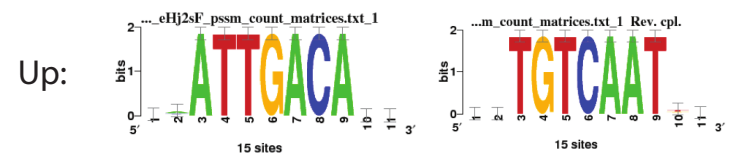

Down:

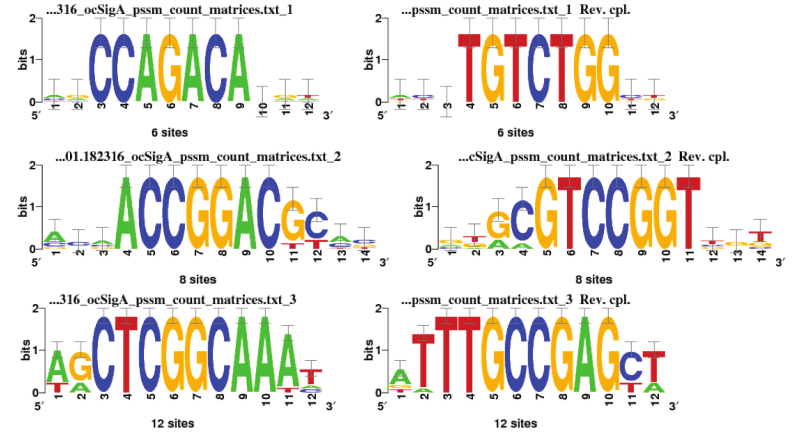

B

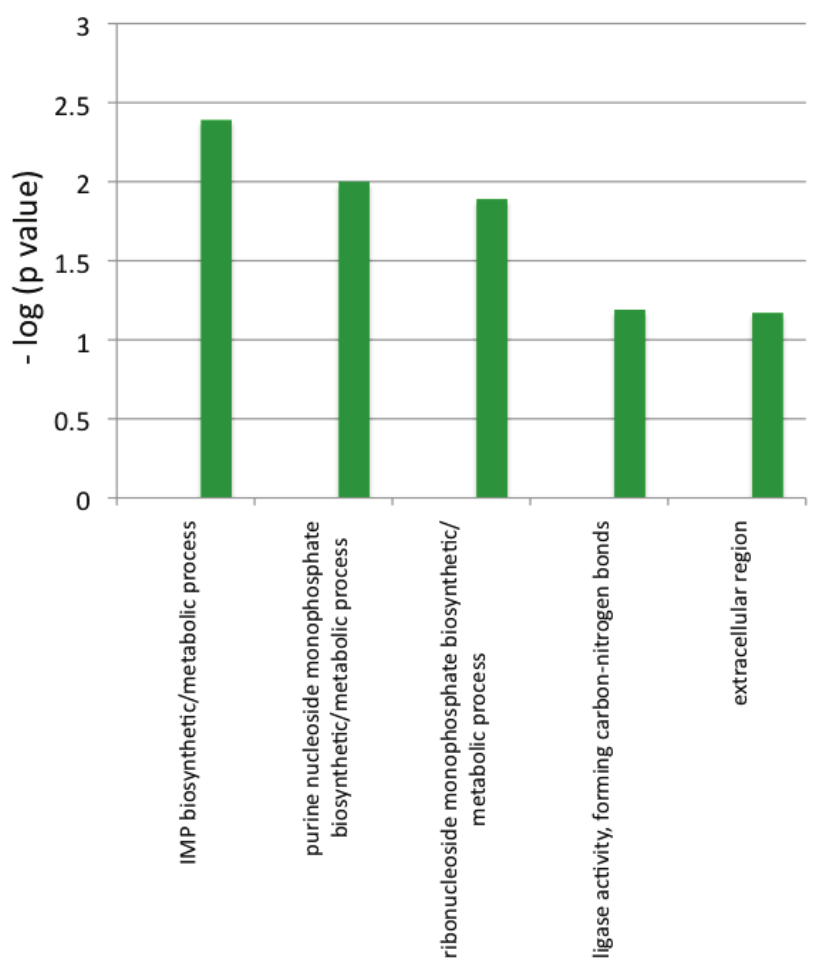

D

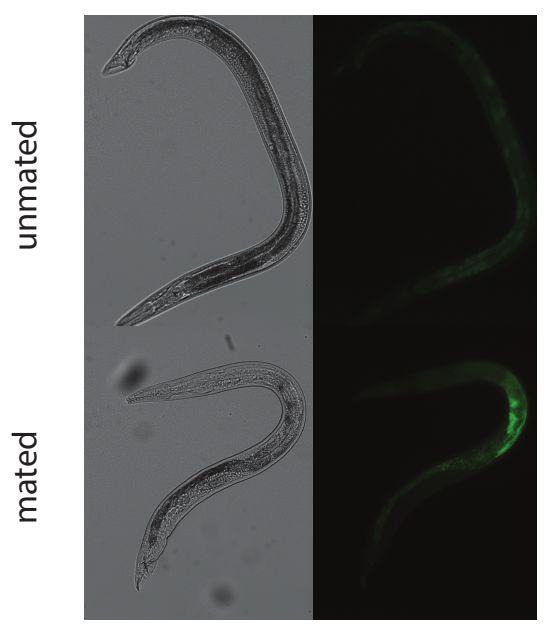

Max vit-2::GFP
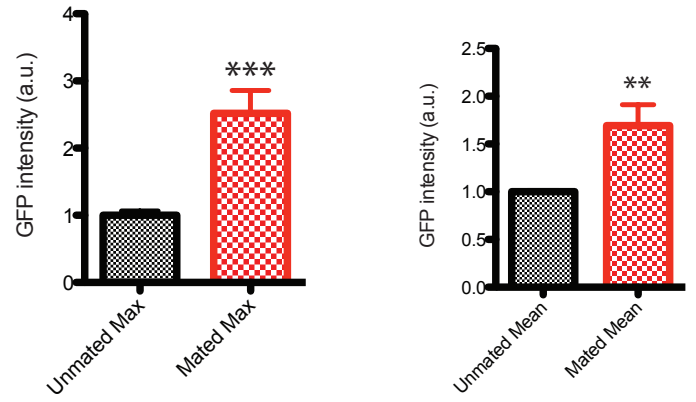
bioRxiv preprint doi: https://doi.org/10.1101/034181; this version posted November 22, 2016. The copyright holder for this preprint (which was not certified by peer review) is the author/funder. All rights reserved. No reuse allowed without permission.

A

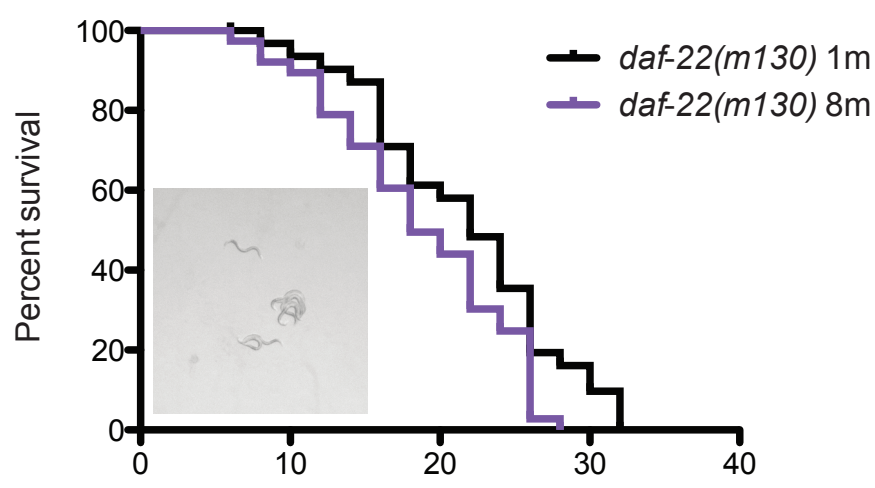

B

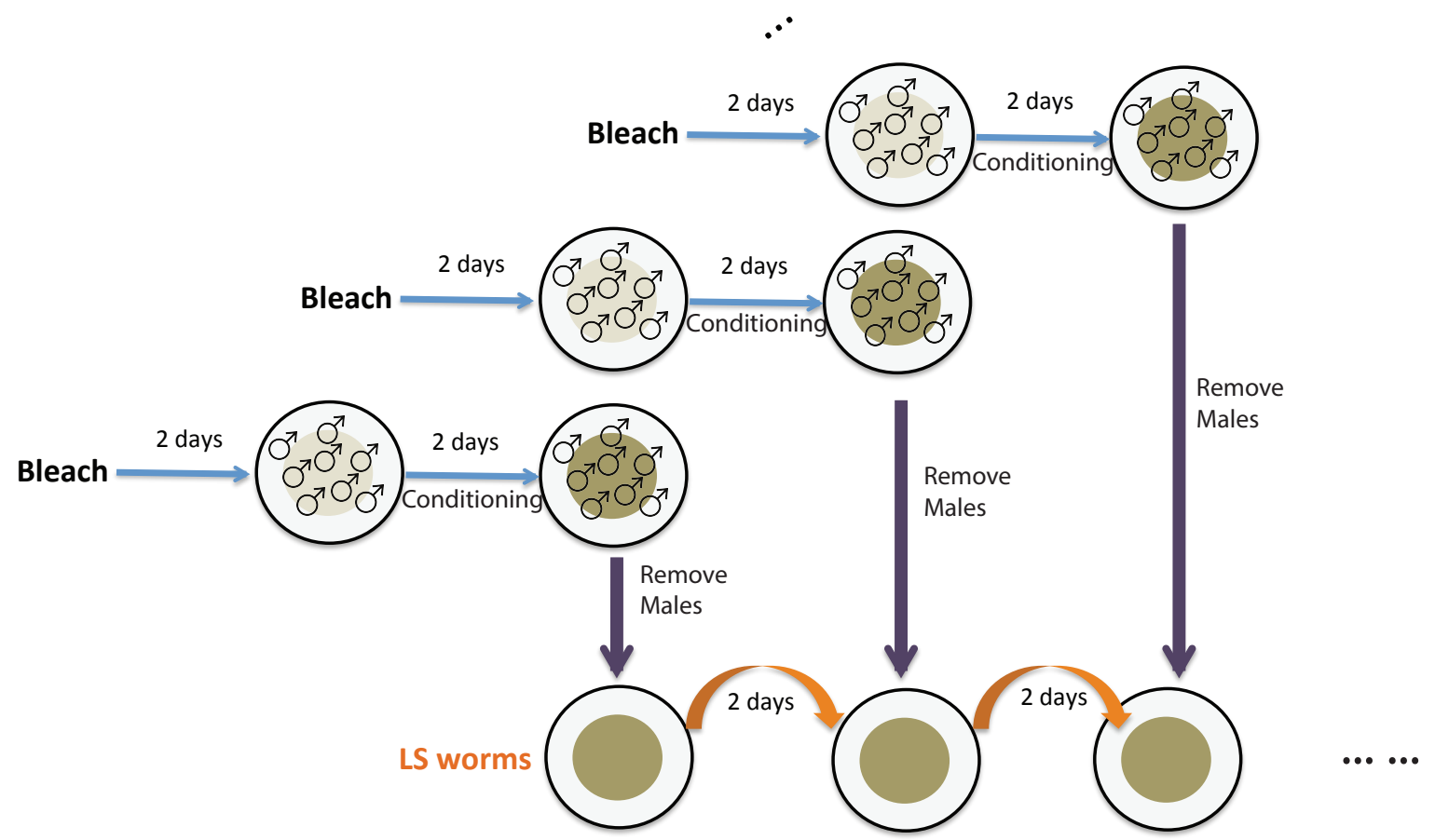


A

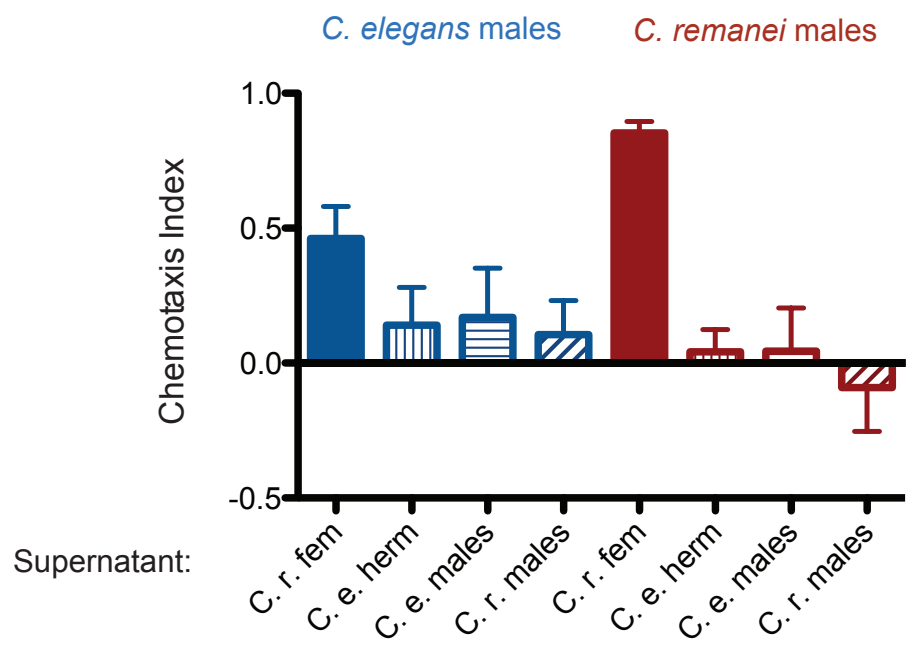

B

Sensitivity to male pheromone

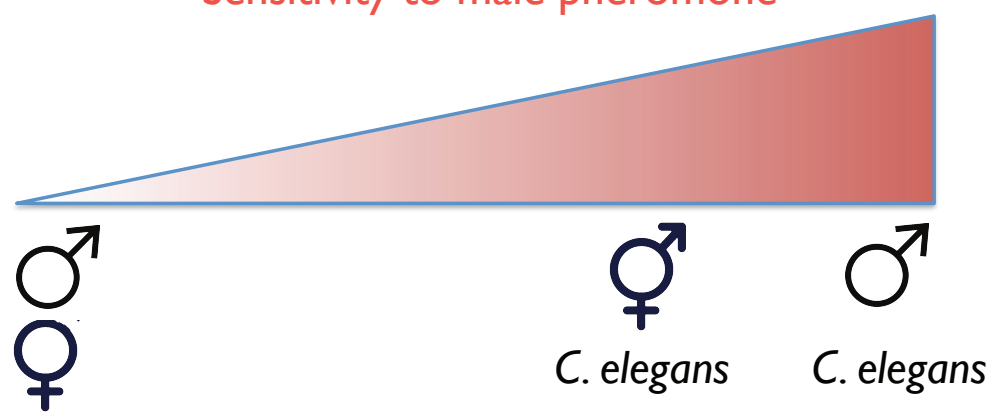

C. remanei

(collateral damage?)

Sex ratio:

$50: 50$

1000:1 


\section{Supplementary Figures:}

Fig. S1 How mating affects male lifespan.

(A) Lifespans of one male paired with different number of hermaphrodites during Day 1-3 of adulthood: solitary unmated males: $10.5 \pm 0.5$ days, $n=35$; one male with one hermaphrodite: $6.6 \pm 0.2$ days, $n=33$, $\mathrm{p}<0.0001$; one male with two hermaphrodites: $6.3 \pm$ 0.2 days, $\mathrm{n}=32, \mathrm{p}<0.0001$; one male with three hermaphrodites: $6.4 \pm 0.3$ days, $\mathrm{n}=31, \mathrm{p}<0.0001$.

(B) Lifespans of one male paired with different number of hermaphrodites for the first 1.7 days of adulthood: solitary unmated males: $12.0 \pm 0.4$ days, $n=40$; one male with one hermaphrodite: $10.6 \pm 0.5$ days, $n=32$, $\mathrm{p}=0.0824$; one male with two hermaphrodites: $9.7 \pm$ 0.6 days, $\mathrm{n}=37, \mathrm{p}=0.0435$; one male with three hermaphrodites: $10.4 \pm 0.6$ days, $\mathrm{n}=36, \mathrm{p}=0.1575$; one male with four hermaphrodites: $9.3 \pm 0.6$ days, $\mathrm{n}=36, \mathrm{p}=0.0041$.

(C) FUdR can rescue male post-mating early death. Unmated solitary males: $13.8 \pm 0.7$ days, $n=35$; one male with one hermaphrodite for six days: $10.3 \pm 0.6$ days, $\mathrm{n}=31, \mathrm{p}=0.0006$; solitary male in the presence of $50 \mu \mathrm{M}$ FUdR: $13.9 \pm 0.4$ days, $\mathrm{n}=35, \mathrm{p}=0.4079$ (compared to unmated solitary group). One male mating with one hermaphrodites for 6 days in the presence of FUdR: $13.6 \pm 0.5$ days, $n=34, p=0.3992$ (compared to unmated solitary group).

(D) Lifespans of males paired with three hermaphrodites for 3 days with FUdR: unmated solitary males: 13.8 \pm 0.7 days, $\mathrm{n}=35$; one male with three hermaphrodites for three days: $10.6 \pm 0.8$ days, $\mathrm{n}=34$, $\mathrm{p}=0.0147$; one male with three hermaphrodites for three days but in the presence of $50 \mu \mathrm{M}$ FUdR during the three days' mating: $14.3 \pm 0.7$ days, $\mathrm{n}=32$, $\mathrm{p}=0.8740$ compared with unmated solitary group.

(E) Lifespans of unmated and mated $g l p-1$ (e2141) males: unmated solitary $g l p-1$ males: $11.1 \pm 1.0$ days, $\mathrm{n}=27$; mated $g l p-1$ males: $11.1 \pm 0.5$ days, $\mathrm{n}=43, \mathrm{p}=0.9149$. The assay was performed at $25^{\circ} \mathrm{C}$, in mated group, one $g l p-1$ male was paired with one fog-2 hermaphrodite from Day 1-6.

\section{Fig. S2 Glycogen staining of mated vs unmated hermaphrodites and males.}

Left: representative pictures of iodine staining of worms. Unmated worms are framed by dashed lines, whereas mated worms are framed by solid lines. In the first picture, mated and unmated fog-2 hermaphrodites were mixed together, with red arrows pointing to mated $f \circ g-2$ hermaphrodites. Worms were mated from Day 1 - Day 5 and were imaged on Day 5.

Right: quantitation of iodine staining. The intensity of mated worms was normalized to unmated control of the same genotype. Mated fog-2 hermaphrodites have $30 \%$ glycogen compared to unmated fog-2 hermaphrodites of the same age $(\mathrm{p}<0.0001)$. Mated glp-1 hermaphrodites have $99 \%$ glycogen compared to unmated $g l p-1$ hermaphrodites control $(\mathrm{p}=0.6070)$. Mated fog- 2 males have $64 \%$ glycogen compared to unmated fog- 2 males of the same age $(\mathrm{p}<0.0001)$. Mated $g l p-1$ males have $101 \%$ glycogen compared to unmated $g l p-1$ males control $(\mathrm{p}=0.7107)$. Error bars represent $\mathrm{SD} .{ }^{* *}, \mathrm{p}<0.0001$, t-test.

\section{Fig. S3 Microarray analysis of mated males.}

(A) Expression heat map of clustered mated males vs unmated males. Individual males were paired with one hermaphrodite for 3.5 days and collected on Day 4 for microarrays.

(B) Enriched GO terms for significantly down-regulated genes in mated males.

(C) Enriched motifs in promoter region (1kb upstream of TSS) of significantly up- and down-regulated genes using (RSAT) Regulatory Sequence Analysis Tools (www.rsat.eu).

(D) VIT-2::GFP expression in males increases significantly after mating. Upper: DIC and GFP images; Lower: GFP intensity quantitation, left: $\max$ $\pm \mathrm{SE}$ (error bars); right: mean $\pm \mathrm{SE}$ (error bars), a.u., arbitrary units. ${ }^{* *}, \mathrm{p}<0.01$, t-test.

Fig. S4 Male pheromone and male-conditioned plates (MCP).

(A) Lifespans of grouped daf-22(m130) males. Solitary males: $21.7 \pm 1.2$ days, $n=32$; eight males: $18.8 \pm 1.0$ days, $\mathrm{n}=38, \mathrm{p}=0.0394$. Inset: daf-22(m130) males also form clumps.

(B) Schematic illustration of how lifespan assays on male-conditioned plates were performed. Detailed description is included in Methods. 


\section{Fig. S5. Male chemotaxis to different pheromones.}

(A) Supernatant solutions from $C$. elegans males, $C$. remanei males, $C$. elegans $\mathrm{N} 2$ hermaphrodites, and $C$. remanei females are used to do the chemotaxis assay. See Methods for detailed description. C. $e$. males to supernatant of $C$. $r$. females: Chemotaxis Index $(\mathrm{CI})$ is $0.46 \pm 0.11$ ( mean \pm SEM, $\mathrm{n}=12$ [plates]); C. e. males to supernatant of $C$. $e$. hermaphrodites: $\mathrm{CI}=0.14 \pm 0.13(\mathrm{n}=10)$; C. e. males to supernatant of $C$. e. males: $\mathrm{CI}=0.17 \pm 0.17$ $(\mathrm{n}=12) ; C . e$. males to supernatant of $C . r$. males: CI $=0.11 \pm 0.12(\mathrm{n}=11) ; C . r$. males to supernatant of $C$. $r$. females: $\mathrm{CI}=0.85 \pm 0.04(\mathrm{n}=12) ; C$. $r$. males to supernatant of $C$. e. hermaphrodites: $\mathrm{CI}=0.04 \pm 0.08$ $(\mathrm{n}=12) ; C . r$. males to supernatant of C. e. males: CI $=0.04 \pm 0.15(\mathrm{n}=12) ; C . r$. males to supernatant of $C$. $r$. males: $\mathrm{CI}=-0.09 \pm 0.16(\mathrm{n}=12)$.

(B) Toxicity scale of sensitivity to male pheromone. 


\section{Supplementary Tables:}

\section{Table S1. Lifespan assays summary}

\begin{tabular}{|c|c|c|c|c|c|}
\hline Genotype/condition & $\begin{array}{l}\text { Mean LS } \pm \\
\text { std. error }\end{array}$ & $\%$ change & $p$ value & $\mathbf{N}$ & $\begin{array}{l}\text { Related } \\
\text { Figure } \\
\end{array}$ \\
\hline \multicolumn{6}{|l|}{ Experiment 1} \\
\hline $1 \mathrm{~m}$ fog-2 & $13.1 \pm 0.6$ & -- & -- & 50 & Fig. 1A \\
\hline $1 \mathrm{f} 1 \mathrm{~m} \_6 \mathrm{~d}$ fog-2 & $8.3 \pm 0.4$ & $-37 \%$ & $<0.0001$ & 34 & Fig. 1A \\
\hline $1 \mathrm{f} 1 \mathrm{~m} \_1.5 \mathrm{~d}$ fog-2 & $11.9 \pm 0.6$ & $-9 \%$ & 0.0988 & 38 & \\
\hline $2 m$ fog-2 & $11.4 \pm 0.5$ & $-13 \%$ & 0.0149 & 48 & \\
\hline $4 \mathrm{~m}$ fog -2 & $9.3 \pm 0.6$ & $-29 \%$ & $<0.0001$ & 48 & \\
\hline \multicolumn{6}{|l|}{ Experiment 2} \\
\hline $1 \mathrm{~m}$ fog-2 & $10.9 \pm 0.6$ & -- & -- & 35 & Fig. 1D \\
\hline $1 \mathrm{f} 1 \mathrm{~m} \_1 \mathrm{~d}$ fog-2 & $11.4 \pm 0.6$ & $+5 \%$ & 0.3697 & 31 & Fig. 1D \\
\hline $1 \mathrm{f} 1 \mathrm{~m} \_2 \mathrm{~d}$ fog-2 & $9.0 \pm 0.6$ & $-17 \%$ & 0.0325 & 30 & Fig. 1D \\
\hline $1 \mathrm{f} 1 \mathrm{~m} \_3 \mathrm{~d}$ fog-2 & $9.1 \pm 0.6$ & $-17 \%$ & 0.0452 & 34 & Fig. 1D \\
\hline $1 \mathrm{f} 1 \mathrm{~m}-4 \mathrm{~d}$ fog-2 & $7.9 \pm 0.5$ & $-28 \%$ & 0.0002 & 32 & Fig. 1D \\
\hline 1f1m_5d fog-2 & $8.3 \pm 0.4$ & $-24 \%$ & 0.0006 & 34 & Fig. 1D \\
\hline $1 \mathrm{f} 1 \mathrm{~m} \_6 \mathrm{~d}$ fog-2 & $6.8 \pm 0.3$ & $-38 \%$ & $<0.0001$ & 33 & Fig. 1D \\
\hline \multicolumn{6}{|l|}{ Experiment 3} \\
\hline $1 \mathrm{~m}$ fog-2 & $13.8 \pm 0.7$ & -- & -- & 35 & Fig. 1E \\
\hline $1 \mathrm{f} 1 \mathrm{~m} \_3 \mathrm{~d}$ fog-2 & $10.8 \pm 0.6$ & $-22 \%$ & 0.0175 & 32 & Fig. 1E \\
\hline $2 \mathrm{f} 1 \mathrm{~m} 3 \mathrm{~d}$ fog-2 & $11.6 \pm 0.9$ & $-16 \%$ & 0.1435 & 33 & Fig. 1E \\
\hline $3 f 1 m \_3 d$ fog-2 & $10.6 \pm 0.8$ & $-23 \%$ & 0.0147 & 34 & Fig. 1E \\
\hline \multicolumn{6}{|l|}{ Experiment 4} \\
\hline $1 \mathrm{~m}$ fog-2 & $10.5 \pm 0.5$ & -- & -- & 35 & Fig. S1A \\
\hline $1 \mathrm{f} 1 \mathrm{~m} 3 \mathrm{~d}$ fog-2 & $6.6 \pm 0.2$ & $-37 \%$ & $<0.0001$ & 33 & Fig. S1A \\
\hline $2 \mathrm{f} 1 \mathrm{~m} 3 \mathrm{~d}$ fog-2 & $6.3 \pm 0.2$ & $-40 \%$ & $<0.0001$ & 32 & Fig. S1A \\
\hline $3 f 1 m \_3 d$ fog-2 & $6.4 \pm 0.3$ & $-39 \%$ & $<0.0001$ & 31 & Fig. S1A \\
\hline \multicolumn{6}{|l|}{ Experiment 5} \\
\hline $1 \mathrm{~m}$ fog-2 & $12.0 \pm 0.4$ & -- & -- & 40 & Fig. S1B \\
\hline $1 \mathrm{f} 1 \mathrm{~m} \_1.7 \mathrm{~d}$ fog-2 & $10.6 \pm 0.5$ & $-12 \%$ & 0.0824 & 32 & Fig. S1B \\
\hline $2 \mathrm{f} 1 \mathrm{~m}-1.7 \mathrm{~d}$ fog-2 & $9.7 \pm 0.6$ & $-19 \%$ & 0.0435 & 37 & Fig. S1B \\
\hline $3 \mathrm{f} 1 \mathrm{~m} \_1.7 \mathrm{~d}$ fog-2 & $10.4 \pm 0.6$ & $-13 \%$ & 0.1575 & 36 & Fig. S1B \\
\hline $4 \mathrm{f} 1 \mathrm{~m} \_1.7 \mathrm{~d}$ fog-2 & $9.3 \pm 0.6$ & $-23 \%$ & 0.0041 & 36 & Fig. S1B \\
\hline \multicolumn{6}{|l|}{ Experiment 6} \\
\hline $1 \mathrm{~m}$ fog-2 & $13.8 \pm 0.7$ & -- & -- & 35 & Fig. 1F \\
\hline $3 f 1 m \_3 d(D 1-3)$ fog-2 & $10.6 \pm 0.8$ & $-23 \%$ & 0.0147 & 34 & Fig. 1F \\
\hline $3 \mathrm{f} 1 \mathrm{~m} \_3 \mathrm{~d}(\mathrm{D} 6-8)$ fog-2 & $10.8 \pm 0.6$ & $-22 \%$ & 0.0022 & 37 & Fig. 1F \\
\hline \multicolumn{6}{|l|}{ Experiment 7} \\
\hline $1 \mathrm{~m}$ fog-2 & $12.1 \pm 0.6$ & -- & $\begin{array}{l}- \\
-\end{array}$ & 32 & Fig. $2 \mathrm{~A}$ \\
\hline $1 \mathrm{f} 1 \mathrm{~m} \_6 \mathrm{~d}$ daf- $22 \times$ fog- 2 & $9.0 \pm 0.4$ & $-26 \%$ & 0.0001 & 29 & Fig. 2A \\
\hline \multicolumn{6}{|l|}{ Experiment 8} \\
\hline $1 \mathrm{~m} d a f-22$ & $13.8 \pm 0.6$ & -- & -- & 40 & Fig. 2B \\
\hline $1 \mathrm{f} 1 \mathrm{~m}$ 6d fog-2 $\mathrm{x}$ daf-22 & $7.4 \pm 0.4$ & $-46 \%$ & $<0.0001$ & 34 & Fig. 2B \\
\hline \multicolumn{6}{|l|}{ Experiment 9} \\
\hline $1 \mathrm{~m}$ fog-2 & $10.5 \pm 0.5$ & -- & -- & 35 & Fig. 2C \\
\hline $3 f 1 m$ 3d fog -2 & $6.4 \pm 0.3$ & $-39 \%$ & $<0.0001$ & 31 & Fig. 2C \\
\hline
\end{tabular}




\begin{tabular}{|c|c|c|c|c|c|}
\hline 3f1m_3d+FUdR fog-2 & $10.2 \pm 0.4$ & $-3 \%$ & 0.7086 & 36 & Fig. $2 \mathrm{C}$ \\
\hline \multicolumn{6}{|l|}{ Experiment 10} \\
\hline $1 \mathrm{~m}$ fog-2 & $13.8 \pm 0.7$ & -- & -- & 35 & Fig. S1C \\
\hline $1 \mathrm{f} 1 \mathrm{~m} \_6 \mathrm{~d}$ fog-2 & $10.3 \pm 0.6$ & $-25 \%$ & 0.0006 & 31 & Fig. S1C \\
\hline $1 \mathrm{~m}+\overline{\mathrm{FU}} \mathrm{dR}$ fog-2 & $13.9 \pm 0.4$ & $+1 \%$ & 0.4079 & 35 & Fig. S1C \\
\hline $1 \mathrm{f} 1 \mathrm{~m} \quad 6 \mathrm{~d}+\mathrm{FUdR}$ fog-2 & $13.6 \pm 0.5$ & $-1 \%$ & 0.3992 & 34 & Fig. S1C \\
\hline $3 f 1 m \_3 d$ fog-2 & $10.6 \pm 0.8$ & $-23 \%$ & 0.0147 & 34 & Fig. S1D \\
\hline $3 f 1 m \_3 d+F U d R$ fog-2 & $14.3 \pm 0.7$ & $+4 \%$ & 0.8740 & 32 & Fig. S1D \\
\hline \multicolumn{6}{|l|}{ Experiment $11 @ 26^{\circ} \mathrm{C}$} \\
\hline $1 \mathrm{~m} g / p-1$ & $8.0 \pm 0.4$ & -- & -- & 40 & Fig. 2D \\
\hline $1 \mathrm{f} 1 \mathrm{~m} \_6 \mathrm{~d}$ fog-2 $\times \mathrm{g} / \mathrm{p}-1$ & $7.2 \pm 0.4$ & $-10 \%$ & 0.3178 & 40 & Fig. 2D \\
\hline \multicolumn{6}{|l|}{ Experiment $12 @ 25^{\circ} \mathrm{C}$} \\
\hline $1 \mathrm{~m} g / p-1$ & $11.1 \pm 1.0$ & -- & -- & 27 & Fig. S1E \\
\hline $1 \mathrm{f} 1 \mathrm{~m} \_6 \mathrm{~d}$ fog-2 $\times \mathrm{g} / \mathrm{p}-1$ & $11.1 \pm 0.5$ & $0 \%$ & 0.9149 & 43 & Fig. S1E \\
\hline \multicolumn{6}{|l|}{ Experiment $13 @ 26^{\circ} \mathrm{C}$} \\
\hline $1 \mathrm{~m} g / p-1$ & $9.6 \pm 0.4$ & -- & -- & 40 & \\
\hline $1 \mathrm{f} 1 \mathrm{~m} \_\mathrm{d}$ fog $-2 \times \mathrm{g} / \mathrm{p}-1$ & $8.8 \pm 0.5$ & $-8 \%$ & 0.238 & 40 & \\
\hline \multicolumn{6}{|l|}{ Experiment 14} \\
\hline $1 \mathrm{~m} \mathrm{pqm-1}$ & $11.9 \pm 0.5$ & -- & -- & 25 & Fig. 3E \\
\hline $1 \mathrm{f} 1 \mathrm{~m}$ 6d fog-2 $\times p q m-1$ & $11.0 \pm 0.6$ & $-8 \%$ & 0.2782 & 29 & Fig. 3E \\
\hline \multicolumn{6}{|l|}{ Experiment 15} \\
\hline $1 \mathrm{~m}$ fog-2 (L4440) & $12.6 \pm 0.7$ & -- & -- & 25 & Fig. 3F \\
\hline 1f1m_4d fog-2 (L4440) & $8.8 \pm 0.5$ & $-30 \%$ & 0.0001 & 33 & Fig. 3F \\
\hline $1 \mathrm{~m}$ fog-2 (unc-62i) & $11.9 \pm 0.8$ & -- & -- & 25 & Fig. 3F \\
\hline 1f1m_4d fog-2 (unc-62i) & $10.6 \pm 0.5$ & $-11 \%$ & 0.1249 & 34 & Fig. 3F \\
\hline \multicolumn{6}{|l|}{ Experiment 16} \\
\hline $1 \mathrm{~m} \mathrm{C.r.}$ & $31.4 \pm 1.7$ & -- & -- & 72 & Fig. 4A \\
\hline $1 \mathrm{f} 1 \mathrm{~m} \_6 \mathrm{~d}$ C. $r$. & $15.7 \pm 1.2$ & $-50 \%$ & $<0.0001$ & 28 & Fig. 4A \\
\hline \multicolumn{6}{|l|}{ Experiment 17} \\
\hline $1 \mathrm{~m} C . e$. & $10.2 \pm 0.6$ & -- & -- & 35 & Fig. 4B \\
\hline $1 \mathrm{~m} 1 \mathrm{f} 6 \mathrm{~d}$ C. e. $\times$ C.e. & $7.4 \pm 0.4$ & $-27 \%$ & 0.0001 & 35 & Fig. 4B \\
\hline $1 \mathrm{~m} 1 \mathrm{f}=6 \mathrm{~d}$ C.r. $\times$ C.e. & $7.4 \pm 0.4$ & $-27 \%$ & 0.0003 & 35 & Fig. 4B \\
\hline \multicolumn{6}{|l|}{ Chinese Emperors LS } \\
\hline Normal & $52.3 \pm 1.0$ & -- & -- & 234 & Fig. 7 \\
\hline Promiscuous & $34.0 \pm 1.9$ & $-35 \%$ & $<0.0001$ & 21 & Fig. 7 \\
\hline \multicolumn{6}{|l|}{ Experiment 18} \\
\hline $1 \mathrm{~m}$ fog-2 & $12.0 \pm 0.4$ & -- & -- & 40 & Fig. 5A \\
\hline $2 m$ fog-2 & $10.6 \pm 0.4$ & $-12 \%$ & 0.0397 & 40 & Fig. 5A \\
\hline $4 m$ fog-2 & $9.9 \pm 0.4$ & $-18 \%$ & 0.0012 & 60 & Fig. $5 \mathrm{~A}$ \\
\hline $8 m$ fog-2 & $7.7 \pm 0.2$ & $-36 \%$ & $<0.0001$ & 80 & Fig. $5 \mathrm{~A}$ \\
\hline \multicolumn{6}{|l|}{ Experiment 19} \\
\hline $1 m+F U d R$ fog- 2 & $13.9 \pm 0.4$ & -- & -- & 35 & Fig. 5B \\
\hline $8 m+F U d R$ fog-2 & $12.4 \pm 0.3$ & $-11 \%$ & 0.0032 & 48 & Fig. 5B \\
\hline $1 \mathrm{~m}$ fog-2 & $138+07$ & -- & -- & 35 & Fia $5 \mathrm{E}$ \\
\hline $8 m$ fog-2 & $9.8 \pm 0.5$ & $-29 \%$ & $<0.0001$ & 48 & Fig. 5E \\
\hline $8 m$ daf-22 & $14.7 \pm 0.7$ & $+7 \%$ & 0.4039 & 48 & Fig. 5E \\
\hline
\end{tabular}




\begin{tabular}{|c|c|c|c|c|c|}
\hline & & & & & \\
\hline $1 \mathrm{~m}+\mathrm{FUdR}$ daf-22 & $15.3 \pm 0.3$ & -- & -- & 35 & Fig. 5F \\
\hline $8 \mathrm{~m}+\mathrm{FUdR}$ daf-22 & $14.7 \pm 0.3$ & $-4 \%$ & 0.2117 & 48 & Fig. 5F \\
\hline $1 \mathrm{~m}$ daf-22 & $17.2 \pm 0.6$ & -- & -- & 35 & \\
\hline $8 m$ daf-22 & $14.7 \pm 0.7$ & $-15 \%$ & 0.0660 & 48 & \\
\hline \multicolumn{6}{|l|}{ Experiment 20} \\
\hline $1 \mathrm{~m}$ daf-22 & $21.7 \pm 1.2$ & -- & -- & 32 & Fig. S4A \\
\hline $8 m$ daf-22 & $18.8 \pm 1.0$ & $-13 \%$ & 0.0394 & 38 & Fig. S4A \\
\hline \multicolumn{6}{|l|}{ Experiment 21} \\
\hline $1 \mathrm{~m}$ C.r. & $37.9 \pm 1.1$ & -- & -- & 120 & Fig. 5C \\
\hline $8 m$ C.r. & $31.0 \pm 0.9$ & $-18 \%$ & $<0.0001$ & 160 & Fig. $5 \mathrm{C}$ \\
\hline \multicolumn{6}{|l|}{ Experiment 22} \\
\hline $1 \mathrm{~m}$ C.r. + FUdR & $30.8 \pm 0.9$ & -- & -- & 45 & Fig. 5D \\
\hline $8 m$ C.r. + FUdR & $30.8 \pm 0.5$ & $0 \%$ & 0.9217 & 112 & Fig. 5D \\
\hline \multicolumn{6}{|l|}{ Experiment 23} \\
\hline $1 \mathrm{~m}$ daf- $22 \mathrm{ctrl}$ & $23.0 \pm 0.9$ & -- & -- & 30 & Fig. $5 G$ \\
\hline $1 \mathrm{~m}$ daf- $22<=1 \mathrm{mMCP}$ & $17.3 \pm 0.7$ & $-25 \%$ & $<0.0001$ & 29 & Fig. $5 \mathrm{G}$ \\
\hline $1 \mathrm{~m}$ daf-22 <=8mMCP & $16.1 \pm 0.6$ & $-30 \%$ & $<0.0001$ & 30 & Fig. $5 G$ \\
\hline \multicolumn{6}{|l|}{ Experiment 24} \\
\hline C.e. herm ctrl & $14.4 \pm 0.8$ & -- & -- & 90 & Fig. 6A \\
\hline C.e. herm <= C.e. MCP & $10.9 \pm 0.6$ & $-24 \%$ & 0.0004 & 60 & Fig. $6 \mathrm{~A}$ \\
\hline C.e. herm <= C.r. MCP & $11.9 \pm 0.5$ & $-17 \%$ & 0.0042 & 90 & Fig. $6 \mathrm{~A}$ \\
\hline C.r. fem ctrl & $15.8 \pm 0.9$ & -- & -- & 60 & Fig. 6B \\
\hline C.r. fem $<=$ C.r. MCP & $19.5 \pm 1.3$ & $+23 \%$ & 0.0636 & 30 & Fig. 6B \\
\hline C.r. fem $<=$ C.e. MCP & $18.5 \pm 0.9$ & $+17 \%$ & 0.1770 & 60 & Fig. 6B \\
\hline \multicolumn{6}{|l|}{ Experiment 25} \\
\hline $1 \mathrm{~m} \mathrm{C.e.}$ & $12.1 \pm 0.6$ & -- & -- & 30 & Fig. 6C \\
\hline $1 \mathrm{~m}<=8 \mathrm{mMCP}$ C.e. & $9.8 \pm 0.4$ & $-19 \%$ & 0.0046 & 28 & Fig. 6C \\
\hline 1f C.e. & $13.8 \pm 0.7$ & -- & -- & 30 & Fig. 6C \\
\hline $1 \mathrm{f}<=8 \mathrm{mMCP}$ C. e. & $12.6 \pm 0.9$ & $-9 \%$ & 0.5965 & 29 & Fig. 6C \\
\hline \multicolumn{6}{|l|}{ Experiment 26} \\
\hline $1 \mathrm{~m}$ C. $r$. & $35.8 \pm 2.0$ & -- & -- & 34 & Fig. 6D \\
\hline $1 \mathrm{~m}<=8 \mathrm{mMCP}$ C. $r$. & $37.8 \pm 1.2$ & $+6 \%$ & 0.8501 & 34 & Fig. 6D \\
\hline 1f C. $r$. & $27.6 \pm 2.2$ & -- & -- & 24 & Fig. 6D \\
\hline $1 \mathrm{f}<=8 \mathrm{mMCP}$ C. $r$. & $27.0 \pm 2.5$ & $-2 \%$ & 0.8306 & 30 & Fig. 6D \\
\hline
\end{tabular}


bioRxiv preprint doi: https://doi.org/10.1101/034181; this version posted November 22, 2016. The copyright holder for this preprint (which was not certified by peer review) is the author/funder. All rights reserved. No reuse allowed without permission.

\section{Table S2. Body size measurements}

\begin{tabular}{|c|c|c|c|c|c|c|c|c|c|}
\hline $\begin{array}{c}\text { Genotype/ } \\
\text { condition }\end{array}$ & $\mathbf{N}$ & & Day 1 & Day 2 & Day 3 & Day 4 & Day 5 & Day 6 & Day 7 \\
\hline $\begin{array}{c}f \text { fog- } 2(q 71) \\
\text { unmated }\end{array}$ & 31 & Body length \pm SE $(\mu \mathrm{m})$ & $903.6 \pm 5.0$ & $961.9 \pm 5.6$ & $982.8 \pm 7.2$ & $976.2 \pm 7.2$ & $959.0 \pm 7.4$ & $935.9 \pm 8.1$ & $931.5 \pm 10.3$ \\
\hline $\begin{array}{c}f o g-2(q 71) \\
\text { mated }\end{array}$ & 30 & & $893.8 \pm 5.1$ & $938.2 \pm 5.6$ & $955.4 \pm 7.1$ & $941.0 \pm 9.5$ & $913.7 \pm 14.0$ & $855.9 \pm 19.4$ & $851.4 \pm 24.5$ \\
\hline \multirow[t]{2}{*}{$@ 20^{\circ} \mathrm{C}$} & & p value & 0.1813 & 0.004 & 0.0088 & 0.0044 & 0.0055 & 0.0004 & 0.0015 \\
\hline & & $\%$ change & $-1.1 \%$ & $-2.5 \%$ & $-2.8 \%$ & $-3.6 \%$ & $-4.7 \%$ & $-8.6 \%$ & $-8.6 \%$ \\
\hline $\begin{array}{c}g l p-1(e 2141) \\
\text { unmated }\end{array}$ & 40 & Body length $\pm S E(\mu \mathrm{m})$ & $789.6 \pm 11.3$ & $880.1 \pm 6.4$ & $894.0 \pm 7.1$ & $895.1 \pm 7.3$ & $888.8 \pm 7.9$ & $872.0 \pm 8.8$ & $874.3 \pm 9.0$ \\
\hline $\begin{array}{c}g I p-1(e 2141) \\
\text { mated }\end{array}$ & 40 & & $789.6 \pm 11.3$ & $887.0 \pm 5.9$ & $892.7 \pm 8.1$ & $894.0 \pm 6.7$ & $888.1 \pm 10.8$ & $868.6 \pm 12.0$ & $857.5 \pm 11.4$ \\
\hline \multirow[t]{2}{*}{$@ 26^{\circ} \mathrm{C}$} & & p value & - & 0.4282 & 0.9083 & 0.9093 & 0.9567 & 0.8173 & 0.2510 \\
\hline & & $\%$ change & - & $0.8 \%$ & $-0.1 \%$ & $-0.1 \%$ & $-0.1 \%$ & $-0.4 \%$ & $-1.9 \%$ \\
\hline
\end{tabular}




\section{Table S3. Mated males microarray SAM rank table}

\section{A. up-regulated genes (compared to unmated control)}

\begin{tabular}{|c|c|c|c|c|c|}
\hline Rank & $\begin{array}{l}\text { Sequence } \\
\text { Name }\end{array}$ & $\begin{array}{l}\text { Gene } \\
\text { Name }\end{array}$ & $\begin{array}{l}\text { Ave. } \\
\text { fold } \\
\text { change }\end{array}$ & $\begin{array}{l}\text { SAM } \\
\text { score }\end{array}$ & Gene description \\
\hline 1 & F59D8.2 & vit-4 & 18.13 & 13.72 & $\begin{array}{l}\text { vit-4 is predicted to have lipid } \\
\text { transporter activity, based on } \\
\text { protein domain information. }\end{array}$ \\
\hline 2 & F59D8.1 & vit-3 & 35.02 & 13.09 & $\begin{array}{l}\text { vit-3 encodes a vitellogenin, a } \\
\text { precursor of the lipid-binding } \\
\text { protein related to vertebrate } \\
\text { vitellogenins and mammalian } \\
\text { ApoB-100, a core LDL particle } \\
\text { constituent (OMIM:107730); VIT- } \\
3 \text { is a major yolk component, but } \\
\text { as loss of VIT-3 activity via RNA- } \\
\text { mediated interference (RNAi) does } \\
\text { not result in any abnormalities, } \\
\text { VIT-3 likely functions redundantly } \\
\text { with other vitellogenins to provide } \\
\text { essential nutrients to the } \\
\text { developing embryo; VIT-3 is } \\
\text { expressed exclusively in the adult } \\
\text { hermaphrodite intestine, from } \\
\text { which it is secreted into the } \\
\text { pseudocoelomic space and finally } \\
\text { taken up by oocytes; in males, } \\
\text { vit-3 expression may be } 3 \text { bating } \\
\text { negatively regulated by MAB-3, a } \\
\text { DM binding domain-containing } \\
\text { transcription factor required for } \\
\text { male sexual development. }\end{array}$ \\
\hline 3 & C04F6. 1 & vit-5 & 13.99 & 11.49 & $\begin{array}{l}\text { vit-5 encodes a vitellogenin, a } \\
\text { lipid-binding protein precursor } \\
\text { related to vertebrate vitellogenins } \\
\text { and mammalian ApoB-100, a core } \\
\text { LDL particle constituent; by } \\
\text { homology, VIT-5 is predicted to } \\
\text { function as a lipid transport } \\
\text { protein; loss of vit-5 activity via } \\
\text { large-scale RNA-mediated } \\
\text { interference (RNAi) screens } \\
\text { indicates that VIT-5 is required for } \\
\text { embryogenesis and normal rates } \\
\text { of postembryonic growth; VIT-5 is } \\
\text { a major yolk component and is } \\
\text { expressed exclusively in the adult } \\
\text { hermaphrodite intestine from } \\
\text { which it is secreted into the } \\
\text { pseudocoelomic space and taken } \\
\text { up by oocytes. }\end{array}$ \\
\hline 4 & $\mathrm{~K} 12 \mathrm{H} 6.5$ & $\mathrm{~K} 12 \mathrm{H} 6.5$ & 6.62 & 10.59 & \\
\hline 5 & K07H8.6 & vit-6 & 21.26 & 10.35 & vitellogenin \\
\hline
\end{tabular}




\begin{tabular}{|c|c|c|c|c|c|}
\hline & & & & & $\begin{array}{l}\text { precursor protein that is cleaved } \\
\text { in the body cavity into two smaller } \\
\text { yolk proteins, YP115 and YP88; in } \\
\text { C. elegans, vitellogenin genes } \\
\text { exhibit stage-, sex-, and tissue- } \\
\text { specific expression being } \\
\text { expressed exclusively in the adult } \\
\text { hermaphrodite intestine. }\end{array}$ \\
\hline 6 & F56H6.2 & F56H6.2 & 4.52 & 8.25 & \\
\hline 7 & Y46H3A.5 & Y46H3A.5 & 4.08 & 8.06 & \\
\hline 8 & C16C8.10 & C16C8.10 & 3.94 & 7.29 & \\
\hline 9 & F56D2.8 & F56D2.8 & 5.03 & 6.73 & \\
\hline 10 & F40G9.15 & F40G9.15 & 3.48 & 6.55 & \\
\hline 11 & C45G7.2 & ilys-2 & 2.85 & 6.28 & $\begin{array}{l}\text { ilys-2 is involved in defense } \\
\text { response to Gram-positive } \\
\text { bacterium; ilys-2 is predicted to } \\
\text { have lysozyme activity, based on } \\
\text { protein domain information. }\end{array}$ \\
\hline 12 & T10D4.7 & T10D4.7 & 4.01 & 6.27 & \\
\hline 13 & C42D8.2 & vit-2 & 13.96 & 6.22 & $\begin{array}{l}\text { vit-2 encodes the vitellogenin } \\
\text { homolog YP170; vit-2 is } \\
\text { expressed in the adult } \\
\text { hermaphrodite intestine and VIT-2 } \\
\text { is secreted into the } \\
\text { pseudocoelomic space before } \\
\text { being taken up by developing } \\
\text { oocytes; vit-2 expression is } \\
\text { regulated in a sex-, stage-, and } \\
\text { tissue-specific manner by the ELT- } \\
2 / G A T A \text { and MAB-3 transcription } \\
\text { factors. }\end{array}$ \\
\hline 14 & C39B5.10 & C39B5.10 & 4.81 & 6.18 & \\
\hline
\end{tabular}

B. down-regulated genes (compared to unmated control)

\begin{tabular}{|l|l|l|l|l|l|}
\hline Rank & $\begin{array}{l}\text { Sequence } \\
\text { Name }\end{array}$ & $\begin{array}{l}\text { Gene } \\
\text { Name }\end{array}$ & $\begin{array}{l}\text { Ave. } \\
\text { fold } \\
\text { change }\end{array}$ & $\begin{array}{l}\text { SAM } \\
\text { score }\end{array}$ & Gene description \\
\hline 1 & F49E11.6 & scl-11 & -23.70 & -15.20 & $\begin{array}{l}\text { Scl-11 encodes a predicted } \\
\text { extracellular protein that is a } \\
\text { member of the C. elegans family } \\
\text { of SCP/TAPS domain-containing } \\
\text { proteins. }\end{array}$ \\
\hline 2 & R04B5.6 & R04B5.6 & -8.11 & -10.76 & $\begin{array}{l}\text { R04B5.6 encodes one of two C. } \\
\text { elegans sorbitol dehydrogense } \\
\text { orthologs; by homology the } \\
\text { product of R04B5.6 is predicted } \\
\text { to catalyze the reversible } \\
\text { oxidation of sorbitol to fructose } \\
\text { in the presence of NAD+; in the } \\
\text { embryo, an R04B5.6:gfp fusion } \\
\text { is expressed in pharyngeal cells } \\
\text { and head neurons. }\end{array}$ \\
\hline 3 & ZK355.3 & ZK355.3 & -15.78 & -10.63 & \multicolumn{2}{|l|}{} \\
\hline 4 & T13B5.5 & lips-11 & -9.76 & -9.88 & lips-11 is predicted to have \\
\hline
\end{tabular}




\begin{tabular}{|c|c|c|c|c|c|}
\hline & & & & & $\begin{array}{l}\text { hydrolase activity, based on } \\
\text { protein domain information. }\end{array}$ \\
\hline 5 & H10D18.2 & $\mathrm{scl}-12$ & -5.82 & -9.38 & $\begin{array}{l}\text { scl-12 encodes a predicted } \\
\text { extracellular protein that is a } \\
\text { member of the C. elegans family } \\
\text { of SCP/TAPS domain-containing } \\
\text { proteins. }\end{array}$ \\
\hline 6 & T13B5.6 & lips-12 & -5.04 & -9.36 & $\begin{array}{l}\text { lips-12 is predicted to have } \\
\text { hydrolase activity, based on } \\
\text { protein domain information. }\end{array}$ \\
\hline 7 & Y6E2A.4 & Y6E2A.4 & -5.22 & -9.26 & \\
\hline 8 & K02E7.6 & K02E7.6 & -7.29 & -9.18 & \\
\hline 9 & F56D6.8 & F56D6.8 & -10.08 & -8.80 & \\
\hline 10 & W10G11.15 & clec- 129 & -10.03 & -8.00 & \\
\hline 11 & F56D6.9 & F56D6.9 & -22.94 & -7.93 & \\
\hline 12 & F38B6.4 & F38B6.4 & -4.20 & -7.49 & $\begin{array}{l}\text { F38B6.4 is an ortholog of human } \\
\text { GART } \\
\text { (phosphoribosylglycinamide } \\
\text { formyltransferase, } \\
\text { phosphoribosylglycinamide } \\
\text { synthetase, } \\
\text { phosphoribosylaminoimidazole } \\
\text { synthetase); F38B6.4 is } \\
\text { predicted have } \\
\text { phosphoribosylamine-glycine } \\
\text { ligase activity, } \\
\text { phosphoribosylformylglycinamidi } \\
\text { ne cyclo-ligase activity, } \\
\text { phosphoribosylglycinamide } \\
\text { formyltransferase activity, and } \\
\text { ATP binding activity, based on } \\
\text { protein domain information. }\end{array}$ \\
\hline 13 & Y22F5A.5 & Iys-2 & -8.30 & -7.46 & $\begin{array}{l}\text { lys-2 is one of ten C. elegans } \\
\text { lysozyme genes; as such, lys- } 2 \\
\text { can be predicted to have a role } \\
\text { in lysozymal function including } \\
\text { immune function. }\end{array}$ \\
\hline 14 & T01C3.11 & T01C3.11 & -4.25 & -7.33 & \\
\hline 15 & F46B3.14 & F46B3.14 & -4.45 & -7.16 & \\
\hline 16 & F45D11.4 & F45D11.4 & -4.15 & -6.70 & $\begin{array}{l}\text { F45D11.4, with F45D11.2 and } \\
\text { F45D11.3, encodes a nematode- } \\
\text { specific protein that entirely } \\
\text { consists of one large ( } \sim 300- \\
\text { residue) 'domain of unknown } \\
\text { function' (DUF684) that is found } \\
\text { in several other C. elegans } \\
\text { proteins; a transcription unit of } \\
\text { either F45D11.4, F45D11.2, or } \\
\text { F45D11.3 (genes of essentially } \\
\text { identical sequence) has a natural } \\
\text { nonsense transcript that is up- } \\
\text { regulated in vivo by smg[-] } \\
\text { mutations, indicating that at } \\
\text { least one of these three genes is } \\
\text { a natural substrate for SMG- } \\
\text { mediated nonsense } \\
\text { suppresssion; since several other } \\
\text { natural mRNA substrates of SMG }\end{array}$ \\
\hline
\end{tabular}




\begin{tabular}{|c|c|c|c|c|c|}
\hline & & & & & $\begin{array}{l}\text { suppression (e.g., rpl-3, rpl-8, } \\
\text { rpl-10a, rpl-12) have protein } \\
\text { products that are involved in } \\
\text { translation, F45D11.4 protein } \\
\text { may may function in translation } \\
\text { as well. }\end{array}$ \\
\hline 17 & F58E10.7 & F58E10.7 & -4.01 & -6.33 & \\
\hline 18 & F32B4.6 & F32B4.6 & -7.31 & -6.19 & $\begin{array}{l}\text { F32B4.6 is an ortholog of human } \\
\text { ABHD11 (abhydrolase domain } \\
\text { containing 11). }\end{array}$ \\
\hline 19 & Y116A8C.44 & Y116A8C.44 & -5.04 & -6.12 & \\
\hline 20 & C52D10.1 & C52D10.1 & -2.97 & -6.09 & \\
\hline 21 & F36G9.7 & F36G9.7 & -3.71 & -6.06 & \\
\hline 22 & F45D11.15 & F45D11.15 & -7.75 & -6.04 & \\
\hline 23 & EGAP7.1 & dpy-3 & -2.52 & -6.04 & $\begin{array}{l}\text { dpy-3 encodes a cuticular } \\
\text { collagen; along with dpy-2, dpy- } \\
7, \text { dpy-8, and dpy-10, dpy-3 is } \\
\text { required postembryonically for } \\
\text { annular furrow formation and/or } \\
\text { maintenance; specifically, DPY-3 } \\
\text { activity is required for proper } \\
\text { assembly of the DPY-7 collagen } \\
\text { into the mature extracellular } \\
\text { matrix; during each cuticle } \\
\text { synthetic period, dpy-3 mRNA is } \\
\text { expressed approximately four } \\
\text { hours prior to the secretion of } \\
\text { new cuticle. }\end{array}$ \\
\hline 24 & C17B7.12 & C17B7.12 & -3.47 & -6.04 & \\
\hline 25 & C32B5.9 & fbxc-7 & -4.85 & -6.03 & \\
\hline 26 & T13B5.7 & lips-13 & -5.67 & -5.99 & $\begin{array}{l}\text { lips-13 is predicted to have } \\
\text { hydrolase activity, based on } \\
\text { protein domain information. }\end{array}$ \\
\hline 27 & F35E8.10 & F35E8.10 & -3.41 & -5.95 & \\
\hline 28 & B0286.3 & B0286.3 & -3.43 & -5.95 & $\begin{array}{l}\text { B0286.3 is an ortholog of human } \\
\text { PAICS } \\
\text { (phosphoribosylaminoimidazole } \\
\text { carboxylase, } \\
\text { phosphoribosylaminoimidazole } \\
\text { succinocarboxamide synthetase); } \\
\text { B0286.3 is predicted to have ATP } \\
\text { binding activity, based on protein } \\
\text { domain information. }\end{array}$ \\
\hline 29 & T01B10.1 & grd-4 & -4.72 & -5.91 & $\begin{array}{l}\text { grd-4 encodes a hedgehog-like } \\
\text { protein, with an N-terminal } \\
\text { signal sequence and a C-terminal } \\
\text { Ground domain; the Ground } \\
\text { domain is predicted to form a } \\
\text { cysteine-crosslinked protein } \\
\text { involved in intercellular } \\
\text { signalling, and it has subtle } \\
\text { similarity to the N-terminal } \\
\text { Hedge domain of HEDGEHOG } \\
\text { proteins; GRD-4 is weakly } \\
\text { required for normal molting; } \\
\text { GRD-4 is also required for } \\
\text { normal adult alae formation, } \\
\text { growth to full size, and }\end{array}$ \\
\hline
\end{tabular}




\begin{tabular}{|c|c|c|c|c|c|}
\hline & & & & & 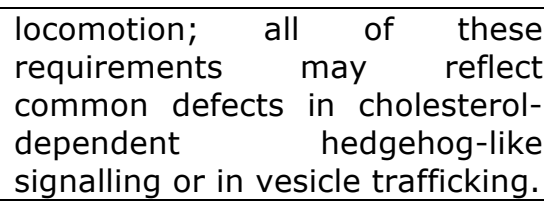 \\
\hline 30 & T22B7.7 & T22B7.7 & -7.06 & -5.90 & $\begin{array}{l}\text { T22B7.7 is an ortholog of human } \\
\text { ACOT9 (acyl-CoA thioesterase } \\
\text { 9). }\end{array}$ \\
\hline 31 & C07A9.9 & C07A9.9 & -3.02 & -5.89 & \\
\hline 32 & C48B4.1 & C48B4.1 & -3.08 & -5.82 & $\begin{array}{l}\text { C48B4.1 is an ortholog of human } \\
\text { ACOX2 (acyl-CoA oxidase 2, } \\
\text { branched chain) and ACOX1 } \\
\text { (acyl-CoA oxidase 1, palmitoyl); } \\
\text { C48B4.1 is predicted to have } \\
\text { acyl-CoA dehydrogenase activity, } \\
\text { acyl-CoA oxidase activity, and } \\
\text { flavin adenine dinucleotide } \\
\text { binding activity, based on protein } \\
\text { domain information. }\end{array}$ \\
\hline 33 & F45D11.1 & F45D11.1 & -5.05 & -5.73 & \\
\hline 34 & C03G6.5 & C03G6.5 & -2.73 & -5.70 & \\
\hline 35 & $\mathrm{C} 10 \mathrm{H} 11.5$ & ugt-27 & -4.36 & -5.65 & $\begin{array}{l}\text { ugt-27 is an ortholog of human } \\
\text { UGT3A2 } \\
\text { glycosyltransferase } 3 \text { family, } \\
\text { polypeptide A2) and UGT3A1 } \\
\text { (UDP glycosyltransferase } 3 \\
\text { family, polypeptide A1); ugt-27 } \\
\text { is predicted to have transferase } \\
\text { activity, transferring hexosyl } \\
\text { groups, based on protein domain } \\
\text { information. }\end{array}$ \\
\hline 36 & C09C7.1 & zig-4 & -2.52 & -5.65 & $\begin{array}{l}\text { zig-4 encodes a predicted } \\
\text { secreted protein that is a } \\
\text { member of the immunoglobulin } \\
\text { superfamily of proteins; ZIG-4 } \\
\text { activity is required for } \\
\text { maintenance of ventral nerve } \\
\text { cord organization: the AVKL/R } \\
\text { and PVQL/R axons of the left and } \\
\text { right ventral nerve cords do not } \\
\text { maintain their proper spatial } \\
\text { positions and drift into the } \\
\text { opposite cord; a zig-4::gfp } \\
\text { reporter fusion is expressed in } \\
\text { the PVT, ASK, BAG, and M2 } \\
\text { neurons, with expression also } \\
\text { seen during the L1 stage in } \\
\text { pharyngeal mesoderm and } \\
\text { ectoderm. }\end{array}$ \\
\hline 37 & F18E3.12 & F18E3.12 & -3.26 & -5.65 & \\
\hline 38 & C33G8.3 & C33G8.3 & -7.08 & -5.62 & \\
\hline 39 & C23G10.6 & C23G10.6 & -3.23 & -5.57 & $\begin{array}{l}\text { C23G10.6 is an ortholog of } \\
\text { human UGT3A2 } \\
\text { glycosyltransferase } 3 \text { family, } \\
\text { polypeptide A2) and UGT3A1 } \\
\text { (UDP glycosyltransferase } 3 \\
\text { family, polypeptide A1); } \\
\text { C23G10.6 is predicted to have }\end{array}$ \\
\hline
\end{tabular}


bioRxiv preprint doi: https://doi.org/10.1101/034181; this version posted November 22, 2016. The copyright holder for this preprint (which was not certified by peer review) is the author/funder. All rights reserved. No reuse allowed without permission.

\begin{tabular}{|l|l|l|l|l|l|}
\hline & & & & $\begin{array}{l}\text { transferase activity, transferring } \\
\text { hexosyl groups, based on protein } \\
\text { domain information. }\end{array}$ \\
\hline 40 & Y53F4B.32 & gst-29 & -2.79 & -5.54 & $\begin{array}{l}\text { gst-29 is an ortholog of human } \\
\text { HPGDS } \\
\text { (hematopoietic } \\
\text { prostaglandin D synthase). }\end{array}$ \\
\hline 41 & Y32G9A.5 & Y32G9A.5 & -2.69 & -5.38 & \\
\hline
\end{tabular}




\section{Table S4. List of Chinese Emperors}

\begin{tabular}{|l|l|}
\hline & Non-promiscuous Emperors, natural death \\
\hline & Non-promiscuous Emperors, unnatural causes \\
\hline & Promiscuous Emperors, natural death \\
\hline & Promiscuous Emperors, unnatural causes \\
\hline
\end{tabular}

\begin{tabular}{|c|c|c|c|c|}
\hline & Name & $\begin{array}{l}\text { Age } \\
\text { at } \\
\text { death }\end{array}$ & $\begin{array}{l}\text { Years } \\
\text { of } \\
\text { reign }\end{array}$ & $\begin{array}{l}\text { Year of birth - } \\
\text { Year of death }\end{array}$ \\
\hline 1 & 秦始皇嬴政 Qin Shi Huang Ying Zheng & 50 & 37 & $259-210 \mathrm{BC}$ \\
\hline 2 & 秦二世 嬴胡亥 Qin Er Shi Ying Huhai & 24 & 3 & $230-207$ BC \\
\hline 3 & 汉高祖 刘邦 Han Gao Zu Liu Bang & 53 & 8 & $247-195$ BC \\
\hline 4 & 汉惠帝 刘盈 Han Hui Di Liu Ying & 23 & 7 & $210-188 \mathrm{BC}$ \\
\hline 5 & 汉文帝 刘恒 Han Wen Di Liu Heng & 46 & 23 & $202-157 \mathrm{BC}$ \\
\hline 6 & 汉景帝 刘启 Han Jing Di Liu Qi & 48 & 16 & $188-141 \mathrm{BC}$ \\
\hline 7 & 汉武帝 刘彻 Han Wu Di Liu Che & 70 & 54 & $156-87 \mathrm{BC}$ \\
\hline 8 & 汉昭帝 刘弗陵 Han Zhao Di Liu Fuling & 21 & 13 & $94-74 \mathrm{BC}$ \\
\hline 9 & 汉宣帝 刘询 Han Xuan Di Liu Xun & 45 & 25 & $91-49 \mathrm{BC}$ \\
\hline 10 & 汉元帝 刘軬 Han Yuan Di Liu Shi & 42 & 16 & $74-33 \mathrm{BC}$ \\
\hline 11 & 汉成帝 刘骜 Han Cheng Di Liu Ao & 45 & 26 & $51-7 \mathrm{BC}$ \\
\hline 12 & 汉哀帝 刘欣 Han Ai Di Liu Xin & 26 & 7 & $26-1 \mathrm{BC}$ \\
\hline 13 & 新朝 王莽 Xin Chao Wang Mang & 68 & 15 & $45 \mathrm{BC}-23$ \\
\hline 14 & 汉光武帝 刘秀 Han Guang Wu Di Liu Xiu & 63 & 32 & $6 \mathrm{BC}-57$ \\
\hline 15 & 汉明帝 刘庄 Han Ming Di Liu Zhuang & 48 & 18 & $28-75$ \\
\hline 16 & 汉章帝 刘炟 Han Zhang Di Liu Da & 32 & 13 & $57-88$ \\
\hline 17 & 汉和帝 刘肇 Han He Di Liu Zhao & 27 & 17 & $79-105$ \\
\hline 18 & 汉安帝 刘祜 Han An Di Liu Hu & 32 & 19 & $94-125$ \\
\hline 19 & 汉顺帝 刘保 Han Shun Di Liu Bao & 30 & 19 & $115-144$ \\
\hline 20 & 汉桓帝 刘志 Han Huan Di Liu Zhi & 36 & 21 & $132-167$ \\
\hline 21 & 汉灵帝 刘宏 Han Ling Di Liu Hong & 34 & 22 & $156-189$ \\
\hline 22 & 汉献帝 刘协 Han Xian Di Liu Xie & 54 & 31 & $181-234$ \\
\hline 23 & 汉昭烈帝 刘备 Han Zhao Lie Di Liu Bei & 63 & 3 & $161-223$ \\
\hline 24 & 蜀汉后主 刘禅 Shu Han Hou Zhu Liu Shan & 65 & 40 & $207-271$ \\
\hline 25 & 魏文帝 曹丕 Wei Wen Di Cao Pi & 40 & 7 & $187-226$ \\
\hline 26 & 魏明帝 曹㕡 Wei Ming Di Cao Rui & 34 & 13 & $205-239$ \\
\hline 27 & 魏齐王 曹芳 Wei Qi Wang Cao Fang & 43 & 15 & $232-274$ \\
\hline 28 & 魏高贵乡公 曹髦 Wei Gao Gui Xiang Gong Cao Mao & 20 & 6 & $241-260$ \\
\hline 29 & 魏元帝 曹英 Wei Yuan Di Cao Huan & 58 & 5 & $245-302$ \\
\hline 30 & 吴大帝 孙权 Wu Da Di Sun Quan & 71 & 24 & $182-252$ \\
\hline 31 & 吴废帝 孙亮 Wu Fei Di Sun Liang & 18 & 6 & $243-260$ \\
\hline 32 & 吴景帝 孙休 Wu Jing Di Sun Xiu & 30 & 6 & $235-264$ \\
\hline 33 & 吴末帝 孙皓 Wu Mo Di Sun Hao & 43 & 16 & $242-284$ \\
\hline 34 & 晋武帝 司马炎 Jin Wu Di Sima Yan & 55 & 25 & $236-290$ \\
\hline 35 & 晋惠帝 司马表 Jin Hui Di Sima Zhong & 48 & 16 & 259-307 \\
\hline 36 & 晋怀帝 司马炽 Jin Huai Di Sima Chi & 30 & 5 & $284-313$ \\
\hline 37 & 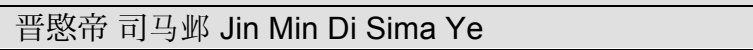 & 18 & 4 & $300-317$ \\
\hline 38 & 晋元帝 司马睿 Jin Yuan Di Sima Yuan & 47 & 5 & $276-323$ \\
\hline 39 & 晋明帝 司马绍 Jin Ming Di Sima Shao & 27 & 3 & $299-325$ \\
\hline 40 & 晋成帝 司马衍 Jin Cheng Di Sima Yan & 22 & 17 & $321-342$ \\
\hline 41 & 晋康帝 司马岳 Jin Kang Di Sima Yue & 23 & 2 & $322-344$ \\
\hline 42 & 晋穆帝 司马聘 Jin Mu Di Sima Dan & 19 & 17 & $343-361$ \\
\hline
\end{tabular}




\begin{tabular}{|c|c|c|c|c|}
\hline 43 & 晋哀帝 司马不 Jin Ai Di Sima Pi & 25 & 4 & $341-365$ \\
\hline 44 & 晋废帝司马奕 Jin Fei Di Sima Yi & 45 & 6 & $342-286$ \\
\hline 45 & 晋简文帝 司马昱 Jin Jian Wen Di Sima Yu & 52 & 1 & $321-372$ \\
\hline 46 & 晋孝武帝司马曜 Jin Xiao Wu Di Sima Yao & 35 & 24 & $362-396$ \\
\hline 47 & 晋安帝 司马德宗 Jin An Di Sima Dezong & 37 & 22 & $382-418$ \\
\hline 48 & 晋恭帝 司马德文 Jin Gong Di Sima Dewen & 37 & 2 & $385-421$ \\
\hline 49 & 楚武悼帝 桓玄 Chu Wu Dao Di Huan Xuan & 36 & 1 & $369-404$ \\
\hline 50 & 成武帝 李雄 Cheng Wu Di Li Xiong & 61 & 30 & $274-334$ \\
\hline 51 & 成幽公 李期 Cheng You Gong Li Qi & 26 & 4 & $314-338$ \\
\hline 52 & 汉昭文帝 李寿 Han Zhaowen Di Li Shou & 44 & 7 & $300-343$ \\
\hline 53 & 后赵明帝 石勒 Hou Zhao Ming Di Shi Le & 60 & 15 & $274-333$ \\
\hline 54 & 后赵海阳王石弘 Hou Zhao Hai Yang Wang Shi Hong & 22 & 1 & $314-335$ \\
\hline 55 & 后赵武帝石虎 Hou Zhao Wu Di Shi Hu & 55 & 15 & $295-349$ \\
\hline 56 & 前燕文明帝 慕容徨 Qian Yan Wen Ming Di Murong Huang & 52 & 12 & $297-348$ \\
\hline 57 & 前燕景昭帝 慕容儶 Qian Yan Jing Zhao Di Murong Jun & 42 & 12 & $319-360$ \\
\hline 58 & 前燕幽帝 慕容暐 Qian Yan You Di Murong Wei & 35 & 10 & $350-384$ \\
\hline 59 & 西燕威帝 慕容冲 Xi Yan Wei Di Murong Chong & 28 & 1 & $359-386$ \\
\hline 60 & 后燕成武帝 慕容垂 Hou Yan Cheng Wu Di Murong Chui & 71 & 12 & $326-396$ \\
\hline 61 & 后燕惠慜帝 慕容宝 Hou Yan Hui Min Di Murong Bao & 44 & 2 & $355-398$ \\
\hline 62 & 后燕昭武帝 慕容盛 Hou Yan Zhao Wu Di Murong Sheng & 29 & 3 & $373-401$ \\
\hline 63 & 后燕昭文帝 慕容熙 Hou Yan Zhao Wen Di Murong Xi & 23 & 6 & $385-407$ \\
\hline 64 & 南燕献武帝 慕容德 Nan Yan Xian Wu Di Murong De & 70 & 7 & $336-405$ \\
\hline 65 & 南燕末主 慕容超 Nan Yan Hou Zhu Murong Chao & 26 & 5 & $385-410$ \\
\hline 66 & 后凉懿武帝 吕光 Hou Liang Yi Wu Wang Lv Guang & 62 & 13 & $338-399$ \\
\hline 67 & 前秦惠武帝 苻洪 Qian Qin Hui Wu Di Fu Hong & 66 & 1 & $285-350$ \\
\hline 68 & 前秦明帝 苻健 Qian Qin Ming Di Fu Jian & 39 & 5 & $317-355$ \\
\hline 69 & 前秦厉王 苻生 Qian Qin Li Wang Fu Sheng & 23 & 2 & $335-357$ \\
\hline 70 & 前秦宣昭帝 苻坚 Qian Qin Xuan Zhao Di Fu Jian & 48 & 28 & $338-385$ \\
\hline 71 & 前秦高帝 苻登 Qian Qin Gao Di Fu Deng & 52 & 8 & $343-394$ \\
\hline 72 & 后秦武昭帝 姚茩 Hou Qin Wu Zhao Di Yao Chang & 64 & 9 & $330-393$ \\
\hline 73 & 后秦文桓帝 姚兴 Hou Qin Wen Huan Di Yao Xing & 51 & 23 & $366-416$ \\
\hline 74 & 后秦末主 姚泓 Hou Qin Mo Zhu Yao Hong & 30 & 1 & $388-417$ \\
\hline 75 & 夏武烈帝 赫连勃勃 Xia Wu Lie Di Helian Bobo & 45 & 18 & $381-425$ \\
\hline 76 & 宋武帝 刘裕 Song Wu Di Liu Yu & 60 & 2 & $363-422$ \\
\hline 77 & 宋少帝 刘义符 Song Shao Di Liu Yifu & 19 & 2 & $406-424$ \\
\hline 78 & 宋文帝 刘义隆 Song Wen Di Liu Yilong & 47 & 29 & $407-453$ \\
\hline 79 & 宋孝武帝 刘骏 Song Xiao Wu Di Liu Jun & 35 & 11 & $430-464$ \\
\hline 80 & 宋明帝 刘或 Song Ming Di Liu Yu & 34 & 7 & $439-472$ \\
\hline 81 & 齐高帝 萧道成 Qi Gao Di Xiao Daocheng & 56 & 4 & $427-482$ \\
\hline 82 & 齐武帝 萧赜 Qi Wu Di Xiao Ze & 54 & 11 & $440-493$ \\
\hline 83 & 齐郁林王 萧昭业 Qi Yu Lin Wang Xiao Zhaoye & 22 & 1 & $473-494$ \\
\hline 84 & 齐明帝 萧变 Qi Ming Di Xiao Luan & 47 & 4 & $452-498$ \\
\hline 85 & 齐东昏侯 萧宝卷 Qi Dong Hun Gou Xiao Baojuan & 19 & 3 & $483-501$ \\
\hline 86 & 梁武帝 萧衍 Liang Wu Di Xiao Yan & 86 & 48 & $464-549$ \\
\hline 87 & 梁简文帝 萧纲 Liang Jian Wen Di Xiao Gang & 49 & 2 & $503-551$ \\
\hline 88 & 梁元帝 萧绎 Liang Yuan Di Xiao Yi & 47 & 3 & $508-554$ \\
\hline 89 & 梁宣帝 萧䇾 Liang Xuan Di Xiao Cha & 44 & 8 & $519-562$ \\
\hline 90 & 梁明帝 萧岁 Liang Ming Di Xiao Kui & 44 & 23 & $542-585$ \\
\hline 91 & 陈武帝 陈霸先 Chen Wu Di Chen Baxian & 57 & 3 & $503-559$ \\
\hline 92 & 陈文帝 陈蒨 Chen Wen Di Chen Qian & 45 & 7 & $522-566$ \\
\hline 93 & 陈宣帝 陈顼 Chen Xuan Di Chen Xu & 53 & 14 & $530-582$ \\
\hline 94 & 陈后主 陈叔宝 Chen Hou Zhu Chen Shubao & 52 & 7 & $553-604$ \\
\hline
\end{tabular}




\begin{tabular}{|c|c|c|c|c|}
\hline 95 & 北魏道武帝 拓跋珪 Bei Wei Dao Wu Di Tuoba Gui & 39 & 24 & $371-409$ \\
\hline 96 & 北魏明元帝 拓跋嗣 Bei Wei Ming Yuan Di Tuoba Si & 32 & 14 & $392-423$ \\
\hline 97 & 北魏太武帝 拓跋奏 Bei Wei Tai Wu Di Tuoba Tao & 45 & 29 & $408-452$ \\
\hline 98 & 北魏文成帝 拓跋濬 Bei Wei Wen Cheng Di Tuoba Jun & 26 & 13 & $440-465$ \\
\hline 99 & 北魏献文帝 拓跋弘 Bei Wei Xian Wen Di Tuoba Hong & 23 & 11 & $454-476$ \\
\hline 100 & 北魏孝文帝 元宏 Bei Wei Xiao Wen Di Yuan Hong & 33 & 23 & $467-499$ \\
\hline 101 & 北魏宣武帝 元恪 Bei Wei Xiao Wu Di Yuan Ke & 33 & 16 & $463-515$ \\
\hline 102 & 北魏孝明帝 元诩 Bei Wei Xiao Ming Di Yuan Xu & 19 & 13 & $510-528$ \\
\hline 103 & 北魏孝庄帝 元子做 Bei Wei Xiao Zhuang Di Yuan Ziyou & 24 & 2 & $507-530$ \\
\hline 104 & 北魏节闵帝元恭 Bei Wei Jie Min Di Yuan Gong & 35 & 1 & $498-532$ \\
\hline 105 & 北魏安定王 元朗 Bei Wei An Ding Wang Yuan Lang & 20 & 1 & $513-532$ \\
\hline 106 & 北魏孝武帝 元修 Bei Wei Xiao Wu Di Yuan Xiu & 25 & 2 & $510-534$ \\
\hline 107 & 东魏孝静帝 元善见 Dong Wei Xiao Jing Di Yuan Jianshan & 28 & 17 & $524-551$ \\
\hline 108 & 西魏文帝 元宝炬 Xi Wei Wen Di Yuan Baoju & 45 & 17 & $507-551$ \\
\hline 109 & 西魏恭帝 拓跋廓 Xi Wei Gong Di Tuoba Kuo & 21 & 3 & $537-557$ \\
\hline 110 & 北齐文宣帝 高洋 Bei Qi Wen Xuan Di Gao Yang & 31 & 10 & $529-559$ \\
\hline 111 & 北齐孝昭帝 高演 Bei Qi Xiao Zhao Di Gao Yan & 27 & 1 & $535-561$ \\
\hline 112 & 北齐武成帝 高湛 Bei Qi Wu Cheng Di Gao Dan & 32 & 4 & $537-568$ \\
\hline 113 & 北齐后主 高纬 Bei Qi Hou Zhu Gao Wei & 21 & 12 & $556-577$ \\
\hline 114 & 北周明帝 宇文毓 Bei Zhou Ming Di Yuwen Yu & 27 & 3 & $534-560$ \\
\hline 115 & 北周武帝 宇文蓑 Bei Zhou Wu Di Yuwen Yong & 36 & 18 & $543-578$ \\
\hline 116 & 北周宣帝 宇文望 Bei Zhou Xuan Di Yuwen Yun & 22 & 1 & $559-580$ \\
\hline 117 & 隋文帝 杨坚 Sui Wen Di Yang Jian & 64 & 24 & $541-604$ \\
\hline 118 & 隋炀帝 杨广 Sui Yang Di Yang Guang & 50 & 14 & $569-618$ \\
\hline 119 & 唐高祖 李渊 Tang Gao Zu Li Yuan & 70 & 9 & $566-635$ \\
\hline 120 & 唐太宗 李世民 Tang Tai Zong Li Shiming & 53 & 23 & $597-649$ \\
\hline 121 & 唐高宗 李治 Tang Gao Zong Li Zhi & 56 & 34 & $628-683$ \\
\hline 122 & 武则天 武眰 Wu Ze Tian Wu Zhao & 82 & 15 & $624-705$ \\
\hline 123 & 唐中宗 李显 Tang Zhong Zong Li Xian & 56 & 6 & $656-710$ \\
\hline 124 & 唐睿宗 李旦 Tang Rui Zong Li Dan & 55 & 8 & $662-716$ \\
\hline 125 & 唐玄宗 李隆基 Tang Xuan Zong Li Longji & 78 & 44 & $685-762$ \\
\hline 126 & 唐肃宗 李亨 Tang Su Zong Li Heng & 52 & 6 & $711-762$ \\
\hline 127 & 唐代宗 李豫 Tang Dai Zong Li Yu & 54 & 17 & $726-779$ \\
\hline 128 & 唐德宗 李适 Tang De Zong Li Shi & 64 & 26 & $742-805$ \\
\hline 129 & 唐顺宗 李诵 Tang Shun Zong Li Song & 46 & 1 & $761-806$ \\
\hline 130 & 唐宪宗 李纯 Tang Xian Zong Li Chun & 43 & 15 & $778-820$ \\
\hline 131 & 唐穆宗 李恒 Tang Mu Zong Li Heng & 30 & 4 & $795-824$ \\
\hline 132 & 唐敬宗 李湛 Tang Jing Zong Li Zhan & 18 & 2 & $809-826$ \\
\hline 133 & 唐文宗 李昂 Tang Wen Zong Li Ang & 32 & 14 & $809-840$ \\
\hline 134 & 唐武宗 李炎 Tang Wu Zong Li Yan & 33 & 6 & $814-846$ \\
\hline 135 & 唐宣宗 李忱 Tang Xuan Zong Li Chen & 50 & 13 & $810-859$ \\
\hline 136 & 唐懿宗 李漼 Tang Yi Zong Li Cui & 41 & 14 & $833-873$ \\
\hline 137 & 唐僖宗 李儇 Tang Xi Zong Li Xuan & 27 & 15 & $862-888$ \\
\hline 138 & 唐昭宗 李晔 Tang Zhao Zong Li Ye & 38 & 16 & $867-904$ \\
\hline 139 & 后梁太祖 朱温 Hou Liang Tai Zu Zhu Wen & 61 & 6 & $852-912$ \\
\hline 140 & 后梁郢王 朱友珪 Hou Liang Ying Wang Zhu Yougui & 30 & 1 & $884-913$ \\
\hline 141 & 后梁末帝 朱友贞 Hou Liang Mo Di Zhu Youzhen & 36 & 10 & $888-923$ \\
\hline 142 & 后唐庄宗 李存县 Hou Tang Zhuang Zong Li Cunxu & 42 & 4 & $885-926$ \\
\hline 143 & 后唐明宗 李嗣源 Hou Tang Ming Zong Li Siyuan & 67 & 7 & $867-933$ \\
\hline 144 & 后唐闵帝 李从厚 Hou Tang Min Di Li Conghou & 21 & 1 & $914-934$ \\
\hline 145 & 后唐末帝 李从珂 Hou Tang Mo Di Li Congke & 52 & 2 & $885-936$ \\
\hline 146 & 后晋高祖 石敬瑭 Hou Jin Gao Zu Shi Jingtang & 51 & 6 & $892-942$ \\
\hline
\end{tabular}




\begin{tabular}{|c|c|c|c|c|}
\hline 147 & 后晋出帝石重贵 Hou Jin Chu Di Shi Chonggui & 61 & 4 & $914-974$ \\
\hline 148 & 后汉高祖 刘知远 Hou Han Gao Zu Liu Zhiyuan & 54 & 1 & $895-948$ \\
\hline 149 & 后汉隐帝 刘承祐 Hou Han Yin Di Liu Chengyou & 20 & 2 & $931-950$ \\
\hline 150 & 北汉世祖 刘崇 Bei Han Shi Zu Liu Chong & 60 & 4 & $895-954$ \\
\hline 151 & 北汉険宗 刘钧 Bei Han Rui Zong Liu Jun & 43 & 14 & $926-968$ \\
\hline 152 & 后周太祖 郭威 Hou Zhou Tai Zu Guo Wei & 51 & 4 & 904-954 \\
\hline 153 & 后周世宗 柴荣 Hou Zhou Shi Zong Chai Rong & 39 & 5 & $921-959$ \\
\hline 154 & 吴太祖 杨行密 Wu Tai Zu Yang Xingmi & 54 & 4 & $852-905$ \\
\hline 155 & 吴烈祖 杨渥 Wu Lie Zu Yang Wo & 23 & 3 & $886-908$ \\
\hline 156 & 吴高祖 杨隆演 Wu Gao Zu Yang Longyan & 24 & 12 & $897-920$ \\
\hline 157 & 吴睿帝 杨溥 Wu Rui Di Yang Pu & 38 & 17 & $900-937$ \\
\hline 158 & 南唐烈祖 李春 Nan Tang Lie Zu Li Bian & 56 & 6 & $888=943$ \\
\hline 159 & 南唐元宗 李璟 Nan Tang Yuan Zong Li Jing & 46 & 8 & $916-961$ \\
\hline 160 & 南唐后主 李显 Nan Tang Hou Zhu Li Yu & 42 & 17 & $937-978$ \\
\hline 161 & 南汉高祖 刘岩 Nan Han Gao Zu Liu Yan & 54 & 31 & $889-942$ \\
\hline 162 & 南汉㱛帝 刘玢 Nan Han Shang Di Liu Bin & 24 & 1 & $920-943$ \\
\hline 163 & 南汉中宗 刘晟 Nan Han Zhong Zong Liu Sheng & 39 & 15 & $920-958$ \\
\hline 164 & 南汉后主 刘鋠 Nan Han Hou Zhu Liu Chang & 38 & 13 & $943-980$ \\
\hline 165 & 前蜀高祖 王建 Qian Shu Gao Zu Wang Jian & 72 & 18 & $847-918$ \\
\hline 166 & 前蜀后主 王衍 Qian Shu Hou Zhu Wang Yan & 28 & 8 & $899-926$ \\
\hline 167 & 后蜀高祖 孟知祥 Hou Shu Gao Zu Meng Zhixiang & 61 & 1 & $874-934$ \\
\hline 168 & 后蜀后主 孟迅 Hou Shu Hou Zhu Meng Chang & 47 & 31 & $919-965$ \\
\hline 169 & 宋太祖 赵匡扸 Song Tai Zu Zhao Kuangyin & 50 & 17 & $927-976$ \\
\hline 170 & 宋太宗 赵光义 Song Tai Zong Zhao Guangyi & 59 & 21 & $939-997$ \\
\hline 171 & 宋真宗 赵恒 Song Zhen Zong Zhao Heng & 55 & 25 & $968-1022$ \\
\hline 172 & 宋仁宗 赵祯 Song Ren Zong Zhao Zhen & 54 & 41 & $1010-1063$ \\
\hline 173 & 宋英宗 赵曙 Song Ying Zong Zhao Shu & 36 & 4 & $1032-1067$ \\
\hline 174 & 宋神宗 赵顼 Song Shen Zong Zhao Xu & 38 & 18 & $1048-1085$ \\
\hline 175 & 宋哲宗 赵煦 Song Zhe Zong Zhao Xu & 25 & 15 & $1076-1100$ \\
\hline 176 & 宋徽宗 赵佶 Song Hui Zong Zhao Ji & 54 & 25 & $1082-1135$ \\
\hline 177 & 宋钦宗 赵桓 Song Qin Zong Zhao Huan & 57 & 2 & $1100-1156$ \\
\hline 178 & 宋高宗 赵构 Song Gao Zong Zhao Gou & 81 & 35 & $1107-1187$ \\
\hline 179 & 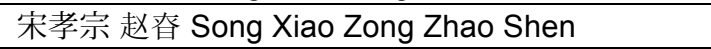 & 68 & 27 & $1127-1194$ \\
\hline 180 & 宋光宗 赵惊 Song Guang Zong Zhao Dun & 54 & 5 & $1147-1200$ \\
\hline 181 & 宋宁宗 赵扩 Song Ning Zong Zhao Kuo & 57 & 30 & $1168-1224$ \\
\hline 182 & 宋理宗 赵昀 Song Li Zong Zhao Yun & 60 & 40 & $1205-1264$ \\
\hline 183 & 宋度宗 赵社 Song Du Zong Zhao Qi & 35 & 10 & $1240-1274$ \\
\hline 184 & 宋恭帝 赵㬎 Song Gong Zong Zhao Xian & 53 & 2 & $1271-1323$ \\
\hline 185 & 辽太祖 耶律阿保机 Liao Tai Zu Yelv Abaoji & 55 & 11 & $872-926$ \\
\hline 186 & 辽太宗 耶律德光 Liao Tai Zong Yelv Deguang & 46 & 21 & $902-947$ \\
\hline 187 & 辽世宗 耶律阮 Liao Shi Zong Yelv Ruan & 34 & 4 & $918-951$ \\
\hline 188 & 辽穆宗 耶律璟 Liao Mu Zong Yelv Jing & 39 & 18 & $931-969$ \\
\hline 189 & 辽景宗 耶律贤 Liao Jing Zong Yelv Xian & 35 & 13 & $948-982$ \\
\hline 190 & 辽圣宗 耶律隆绪 Liao Sheng Zong Yelv Longxu & 61 & 49 & $971-1031$ \\
\hline 191 & 辽兴宗 耶律宗真 Liao Xing Zong Yelv Zongzhen & 40 & 24 & $1016-1055$ \\
\hline 192 & 辽道宗 耶律洪基 Liao Dao Zong Yelv Hongji & 70 & 46 & $1032-1101$ \\
\hline 193 & 辽天祚帝 耶律延禧 Liao Tian Zuo Di Yelv Yanxi & 54 & 24 & $1075-1128$ \\
\hline 194 & 辽宣宗 耶律淳 Liao Xuan Zong Yelv Chun & 61 & 1 & $1062-1122$ \\
\hline 195 & 辽德宗 耶律大石 Liao De Zong Yelv Dashi & 57 & 12 & $1087-1143$ \\
\hline 196 & 金太祖 完颜阿骨打 Jin Tai Zu Wanyan Aguda & 56 & 9 & $1068-1123$ \\
\hline 197 & 金太宗 完颜晟 Jin Tai Zong Wanyan Sheng & 61 & 12 & $1075-1135$ \\
\hline 198 & 金熙宗 完颜亶 Jin Xi Zong Wanyan Dan & 31 & 14 & $1119-1149$ \\
\hline
\end{tabular}




\begin{tabular}{|c|c|c|c|c|}
\hline 199 & 金海陵王 完颜亮 Jin Hai Ling Wang Wanyan Liang & 40 & 12 & $1122-1161$ \\
\hline 200 & 金世宗 完颜雍 Jin Shi Zong Wanyan Yong & 67 & 28 & $1123-1189$ \\
\hline 201 & 金章宗 完颜璟 Jin Zhang Zong Wanyan Jing & 41 & 19 & $1168-1208$ \\
\hline 202 & 金卫绍王 完颜永济 Jin Wei Shao Wang Wanyan Yongji & 61 & 5 & $1153-1213$ \\
\hline 203 & 金宣宗 完颜珣 Jin Xuan Zong Wanyan Xun & 61 & 10 & $1163-1223$ \\
\hline 204 & 金哀宗 完颜守绪 Jin Ai Zong Wanyan Shouxu & 37 & 11 & $1198-1234$ \\
\hline 205 & 夏景宗 李元吴 Xia Jing Zong Li Yuanhao & 46 & 17 & $1003-1048$ \\
\hline 206 & 夏毅宗 李谅祚 Xia Yi Zong Li Liangzuo & 21 & 19 & $1047-1067$ \\
\hline 207 & 夏惠宗 李秉常 Xia Hui Zong Li Bingchang & 26 & 19 & $1061-1086$ \\
\hline 208 & 夏崇宗 李乾顺 Xia Chong Zong Li Qianshun & 57 & 53 & 1083-1139 \\
\hline 209 & 夏仁宗 李仁孝 Xia Ren Zong Li Renxiao & 70 & 54 & $1124-1193$ \\
\hline 210 & 夏桓宗 李纯祐 Xia Huan Zong Li Chunyou & 30 & 13 & $1177-1206$ \\
\hline 211 & 夏襄宗 李安全 Xia Xiang Zong Li Anquan & 42 & 5 & $1170-1211$ \\
\hline 212 & 夏神宗 李遵顼 Xia Shen Zong Li Zunxu & 64 & 12 & $1163-1226$ \\
\hline 213 & 夏献宗 李德旺 Xia Xian Zong Li Dewang & 46 & 3 & $1181-1226$ \\
\hline 214 & 元太祖 铁木真 Yuan Taizu Tie Mu Zhen & 66 & 22 & $1162-1227$ \\
\hline 215 & 元睿宗 拖雷 Yuan Rui Zong Tuo Lei & 41 & 2 & $1192-1232$ \\
\hline 216 & 元太宗 窝阔台 Yuan Tai Zong Wo Kuo Tai & 56 & 13 & $1186-1241$ \\
\hline 217 & 元定宗 贵由 Yuan Ding Zong Gui You & 43 & 3 & $1206-1248$ \\
\hline 218 & 元宪宗 蒙哥 Yuan Xian Zong Meng Ge & 52 & 9 & $1208-1259$ \\
\hline 219 & 元世祖 忽必烈 Yuan Shi Zu Hu Bi Lie & 79 & 35 & $1215-1294$ \\
\hline 220 & 元成宗 铁穆耳 Yuan Cheng Zong Tie Mu Er & 43 & 13 & $1265-1307$ \\
\hline 221 & 元武宗 海山 Yuan Wu Zong Hai Shan & 31 & 4 & $1281-1311$ \\
\hline 222 & 元仁宗 爱育黎拔力八达 Yuan Ren Zong Aiyulibalibada & 36 & 9 & $1285-1320$ \\
\hline 223 & 元英宗 硕德八刺 Yuan Ying Zong Shuo De Ba La & 21 & 3 & $1303-1323$ \\
\hline 224 & 元泰定帝也孙铁木儿 Yuan Tai Ding Di Ye Sun Tie Mu Er & 36 & 5 & $1293-1328$ \\
\hline 225 & 元文宗 图帖睦尔 Yuan Wen Zong Tu Tie Mu Er & 29 & 4 & $1304-1332$ \\
\hline 226 & 元明宗 和世㻋 Yuan Ming Zong He Shi La & 30 & 1 & $1300-1329$ \\
\hline 227 & 元惠宗 妥懽帖睦尔 Yuan Hui Zong Tuo Huan Tie Mu Er & 51 & 38 & $1320-1370$ \\
\hline 228 & 元昭宗 爱奠识理达腊 Yuan Zhao Zong Ai Yu Shi Li Da La & 40 & 8 & $1339-1378$ \\
\hline 229 & 元天元帝 脱古思帖木儿 Yuan Tian Yuan Di Tuogusi Tie MuEr & 47 & 10 & $1342-1388$ \\
\hline 230 & 明太祖 朱元璋 Ming Tai Zu Zhu Yuanzhang & 71 & 31 & $1328-1398$ \\
\hline 231 & 明惠宗 朱允炇 Ming Hui Zong Zhu Yunwen & 26 & 4 & $1377-1402$ \\
\hline 232 & 明成祖 朱棣 Ming Cheng Zu Zhu Di & 65 & 22 & $1360-1424$ \\
\hline 233 & 明仁宗 朱高炽 Ming Ren Zong Zhu Gao Chi & 48 & 1 & $1378-1425$ \\
\hline 234 & 明宣宗 朱瞻基 Ming Xuan Zong Zhu Zhan Ji & 38 & 10 & $1398-1435$ \\
\hline 235 & 明英宗 朱祁镇 Ming Ying Zong Zhu Qizhen & 38 & 22 & $1427-1464$ \\
\hline 236 & 明代宗 朱祁钰 Ming Dai Zong Zhu Qiyu & 30 & 7 & $1428-1457$ \\
\hline 237 & 明宪宗 朱见深 Ming Xian Zong Zhu Jianshen & 41 & 23 & $1447-1487$ \\
\hline 238 & 明孝宗 朱祐樘 Ming Xiao Zong Zhu Youtang & 36 & 18 & $1470-1505$ \\
\hline 239 & 明武宗 朱厚照 Ming Wu Zong Zhu Houzhao & 31 & 16 & $1491-1521$ \\
\hline 240 & 明世宗 朱厚熜 Ming Shi Zong Zhu Houcong & 60 & 45 & $1507-1567$ \\
\hline 241 & 明穆宗 朱载厔 Ming Mu Zong Zhu Zaihou & 36 & 6 & $1537-1572$ \\
\hline 242 & 明神宗 朱靖钧 Ming Shen Zong Zhu Yijun & 58 & 48 & $1563-1620$ \\
\hline 243 & 明囍宗 朱由校 Ming Xi Zong Zhu Youjiao & 23 & 7 & $1605-1627$ \\
\hline 244 & 明思宗 朱由检 Ming Si Zong Zhu Youjian & 35 & 17 & $1610-1644$ \\
\hline 245 & 清太祖 努尔哈赤 Qing Tai Zu Nu Er Ha Chi & 68 & 11 & $1559-1626$ \\
\hline 246 & 清太宗 皇太极 Qing Tai Zong Huang Tai Ji & 52 & 17 & $1592-1643$ \\
\hline 247 & 清世祖 福临 Qing Shi Zu Fu Lin & 24 & 18 & $1638-1661$ \\
\hline 248 & 清圣祖 玄烨 Qing Sheng Zu Xuan Ye & 69 & 61 & $1654-1722$ \\
\hline 249 & 清世宗 胤禵 Qing Shi Zong Yin Zhen & 58 & 13 & $1678-1735$ \\
\hline 250 & 清高宗 弘历 Qing Gao Zong Hong Li & 89 & 60 & $1711-1799$ \\
\hline
\end{tabular}


bioRxiv preprint doi: https://doi.org/10.1101/034181; this version posted November 22, 2016. The copyright holder for this preprint (which was not certified by peer review) is the author/funder. All rights reserved. No reuse allowed without permission.

\begin{tabular}{|l|l|l|l|l|}
\hline 251 & 清仁宗 颙琰 Qing Ren Zong Yong Yan & 61 & 25 & $1760-1820$ \\
\hline 252 & 清宣宗 旻宁 Qing Xuan Zong Min Ning & 69 & 30 & $1782-1850$ \\
\hline 253 & 清文宗 奕詝 Qing Wen Zong Yi Zhu & 31 & 11 & $1831-1861$ \\
\hline 254 & 清穆宗 载淳 Qing Mu Zong Zai Chun & 19 & 13 & $1856-1874$ \\
\hline 255 & 清德宗 载活 Qing De Zong Zai Tian & 38 & 34 & $1871-1908$ \\
\hline
\end{tabular}

